\title{
Reconstruction of burial history, temperature, source rock maturity and hydrocarbon generation in the northwestern Dutch offshore
}

\author{
R. Abdul Fattah ${ }^{*}$, J.M. Verweij, N. Witmans \& J.H. ten Veen
}

TN0 - Geological Survey of the Netherlands, P.0. Box 80015, 3508 TA Utrecht, the Netherlands.

* Corresponding author. Email: rader.abdulfattah@tno.nl

Manuscript received: August 2011, accepted: January 2012

\begin{abstract}
$3 \mathrm{D}$ basin modelling is used to investigate the history of maturation and hydrocarbon generation on the main platforms in the northwestern part of the offshore area of the Netherlands. The study area covers the Cleaverbank and Elbow Spit Platforms. Recently compiled maps and data are used to build the input geological model. An updated and refined palaeo water depth curve and newly refined sediment water interface temperatures (SWIT) are used in the simulation. Basal heat flow is calculated using tectonic models. Two main source rock intervals are defined in the model, Westphalian coal seams and pre-Westphalian shales, which include Namurian and Dinantian successions. The modelling shows that the preWestphalian source rocks entered the hydrocarbon generation window in the Late Carboniferous. In the southern and central parts of the study area, the Namurian started producing gas in the Permian. In the north, the Dinantian source rocks appear to be immature. Lower Westphalian sediments started generating gas during the Upper Triassic. Gas generation from Westphalian coal seams increased during the Paleogene and continues in present-day. This late generation of gas from Westphalian coal seams is a likely source for gas accumulations in the area.

Westphalian coals might have produced early nitrogen prior to or during the main gas generation occurrence in the Paleogene. Namurian shales may be a source of late nitrogen after reaching maximum gas generating phase in the Triassic. Temperatures reached during the Mid Jurassic were sufficiently high to allow the release of non-organic nitrogen from Namurian shales.
\end{abstract}

Keywords: Hydrocarbon generation modelling, Cleaverbank Platform, Elbow Spit Platform, Westphalian source rocks, Namurian shales, Heat flow modelling, Gas generation, Dutch Offshore.

\section{Introduction}

This paper presents results of 3D basin modelling of the burial history and the history of temperature, source rock maturity and timing of hydrocarbon generation in the offshore Netherlands from $320 \mathrm{Ma}$ to present day. The study area is predominantly a platform area which includes the Cleaverbank and Elbow Spit platforms (CP and ESP respectively; Fig. 1). The platforms form an important gas producing area in the Dutch offshore. Gas is produced from both Westphalian and Upper Rotliegend sandstones. Not much is known about the gas source and charge. It is anticipated that the reservoirs are charged from Westphalian coal seams and possibly also from pre-Westphalian source rocks (Gerling et al., 1999; De Jager \& Geluk, 2007).
As a result of the declining production from Rotliegend fields, Carboniferous reservoirs are gaining more attention. This is especially the case towards the north of the study area where Rotliegend sandstones are pinching out. Understanding the maturity evolution of the Westphalian and pre-Westphalian source rocks is thus essential for evaluating Carboniferous plays in the area. This might also shed more light on the occurrence of locally high nitrogen contents in gas fields in the area. The nitrogen content of natural gas accumulations in the study area varies from $<10 \mathrm{Mol} \%$ to very high values in Carboniferous reservoirs (>80 Mol \% in the D blocks). In this study, basin modelling is used to reconstruct key elements and processes important for evaluating the petroleum systems. This includes burial history (sedimentation and erosion history), basal heat flow history as well as history of temperature and source rock 
maturity. The focus is on Westphalian and pre-Westphalian (Namurian and Dinantian) source rocks. We used the results of the TNO mapping program (see Kombrink et al., this issue) including a new 3D stratigraphic model and petrophysical properties. New boundary conditions are applied such as newly constructed basal heat flow models and updated and refined palaeo sediment water interface temperatures and palaeo water depths. Model calibration data, such as temperature and vitrinite reflectance are derived from an updated in-house database.

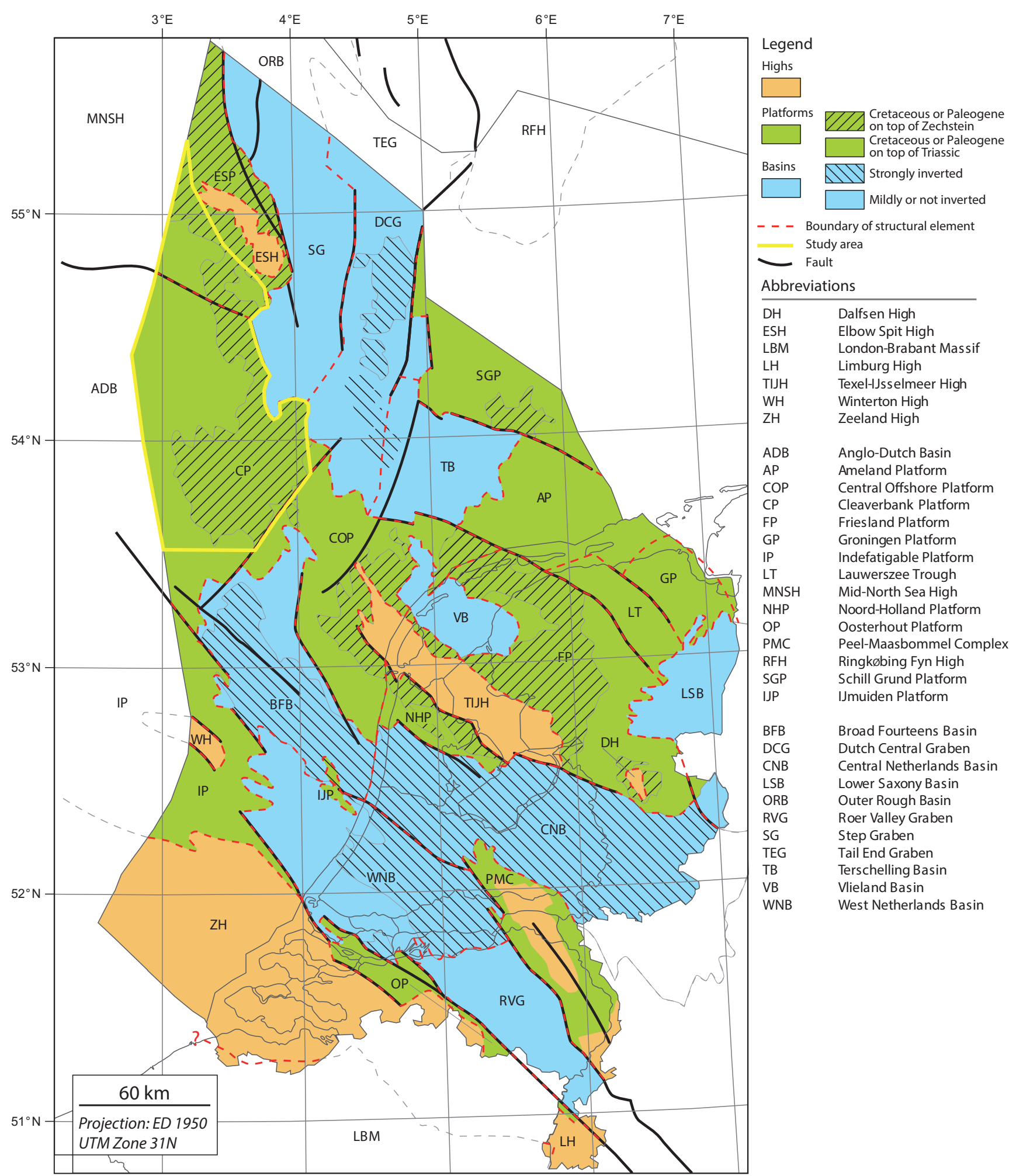

Fig. 1. Major structural elements in the Netherlands with the location of the study area. The outline of the study area is nearly the same as the outline of the NCP-2D subarea (not shown). 


\section{Geological setting}

The stratigraphic succession present in the study area is given in Fig. 2. A detailed and extensive overview of the regional geology and petroleum geology of the Netherlands and the Cleaverbank Platform is presented by Quirk (1993), TNO-NITG (2004), Duin et al. (2006) and Wong et al. (2007) and references therein. This geological setting is based on these publications and on the results of the recently completed mapping project (Kombrink et al., this issue).

The Cleaverbank Platform covers the D, E, K, and western L quadrants. The eastern margin of the platform is defined by a complex set of NW-SE and N-S normal faults underlying the Zechstein salt. Important phases of the geodynamic history of the area include the Saalian phase of uplift and erosion, Triassic extension and subsidence, Mid and Late Kimmerian erosion and rifting, and Sub-Hercynian and Laramide inversion phases.

During the Early Carboniferous, the Netherlands was located in the foreland basin of the Variscan orogen (De Jager, 2007). The collapse of the Variscan orogen at the CarboniferousPermian transition caused regional thermal uplift and erosion of parts of the Upper Carboniferous deposits (Saalian erosion phase). Uplift was followed by thermal relaxation and regional subsidence, leading to the deposition of a succession of aeolian and fluvial sediments (Slochteren Formation) and desert lake deposits (Silverpit Formation) of the Upper Rotliegend Group in the Late Permian (Van Wees et al., 2000; Doornenbal \& Stevenson, 2010). These sediments were subsequently buried by evaporites, carbonates and clays of the Zechstein Group.

Deposition on the platform areas continued until Mid Jurassic times, although the succession was probably more condensed than in the Mesozoic extensional basins to the east. In the Mid Jurassic, thermal doming led to the uplift of much of the area (Ziegler, 1990; De Jager, 2007). This phase of uplift is attributed to rifting in combination with a global fall in sea level and caused widespread erosion in the platform areas (Mid and Late Kimmerian; Ziegler, 1990; De Jager, 2007). Lower Jurassic and Upper Triassic strata were completely removed in places (Quirk, 1993).

In Early Cretaceous times eustatic sea level rose. The area was gradually inundated and deposition of siliciclastic sediments took place. Regional thermal subsidence prevailed. The Late Cretaceous is characterised by deposition of a thick succession of limestones belonging to the Chalk Group. The present-day thickness of Chalk Group varies over the area but increases southwards. Cenozoic sediments unconformably overlie the Chalk Group.

\section{Petroleum systems}

Figure 3 shows the distribution of gas fields in the area. Gas is reservoired in sandstone units of the Limburg and Upper Rotliegend groups. Carboniferous reservoirs have been found in the Westphalian A and B (Botney Mbr) and Westphalian C and
D (Hospital Ground Fm.; Fig. 2). The fields are concentrated in the northern $\mathrm{K}$ and southern $\mathrm{D}$ and $\mathrm{E}$ quadrants at depths around 3500 to $4000 \mathrm{~m}$. Westphalian sandstones in the Cleaverbank Platform were deposited by fluvial systems from northerly sources. The reservoir quality deteriorates southward (De Jager \& Geluk, 2007). Rotliegend reservoirs (Slochteren Formation) are located in the $\mathrm{D}$ and $\mathrm{K}$ quadrants in the southern sector of the Cleaverbank Platform. To the north, the Slochteren sandstones shale out into the Silverpit Formation. In the northern $\mathrm{K}$ blocks and adjacent areas, the shaly Silverpit Formation provides a seal for the underlying basal Slochteren sandstone (De Jager \& Geluk, 2007), but the main top seal is the Zechstein evaporite unit that covers large parts of the area.

The gas source is still largely unknown. Based on geochemical analysis of gas samples from Carboniferous reservoirs, Gerling et al. (1999) suggest that the accumulated gas is a mixture of terrestrial and marine source rocks. Gerling et al. (1999) suggested that most of the gases could have been generated from sapropelic marine source rocks. The postulated marine source rocks could either be Namurian or Dinantian shales. The possible contribution of pre-Westphalian source rocks to gas reservoirs in the area is also proposed by Schroot et al. (2006). These workers showed that the pre-Westphalian might have charged the reservoirs in the eastern and southern margins of the Elbow Spit Platform. In addition to the pre-Westphalian deposits (Namurian and Dinantian), the Coal Measures of the Carboniferous Limburg Group are thought to have contributed to the gas accumulations too (Gerling et al., 1999).

The Dinantian source rock, which subcrops the Permian in the northern part of the study area, comprises deltaic coal bearing sediments of the Farne Group. The total organic carbon (TOC) in these sediments is between $0.89-1.87 \%$ and the organic matter is of type III kerogen (Gerling et al., 1999; Schroot et al., 2006). The Namurian source rocks in the area consist of marine and deltaic sediments known as the Millstone Grit and Epen formations. Namurian shales may include good source rocks of type II kerogen (Gerling et al., 1999). The coal bearing source rocks of the Westphalian Maurits and Klaverbank formations are of kerogen type III.

\section{Basin modelling: input and boundary conditions}

1D-3D Basin modelling (PetroMod version 11 of Schlumberger) is used to evaluate the burial, temperature and maturity history of the area. The data requirements include depth grids of the studied formations, lithological properties, a time-line of tectonic events, boundary conditions and calibration data. The results of the offshore mapping project (Kombrink et al., this issue) provided the present-day stratigraphic and structural framework. Calibration data (temperatures, porosities, permeabilities, pressures, vitrinite reflectance values) required for the numerical modelling are available from an in-house database. 


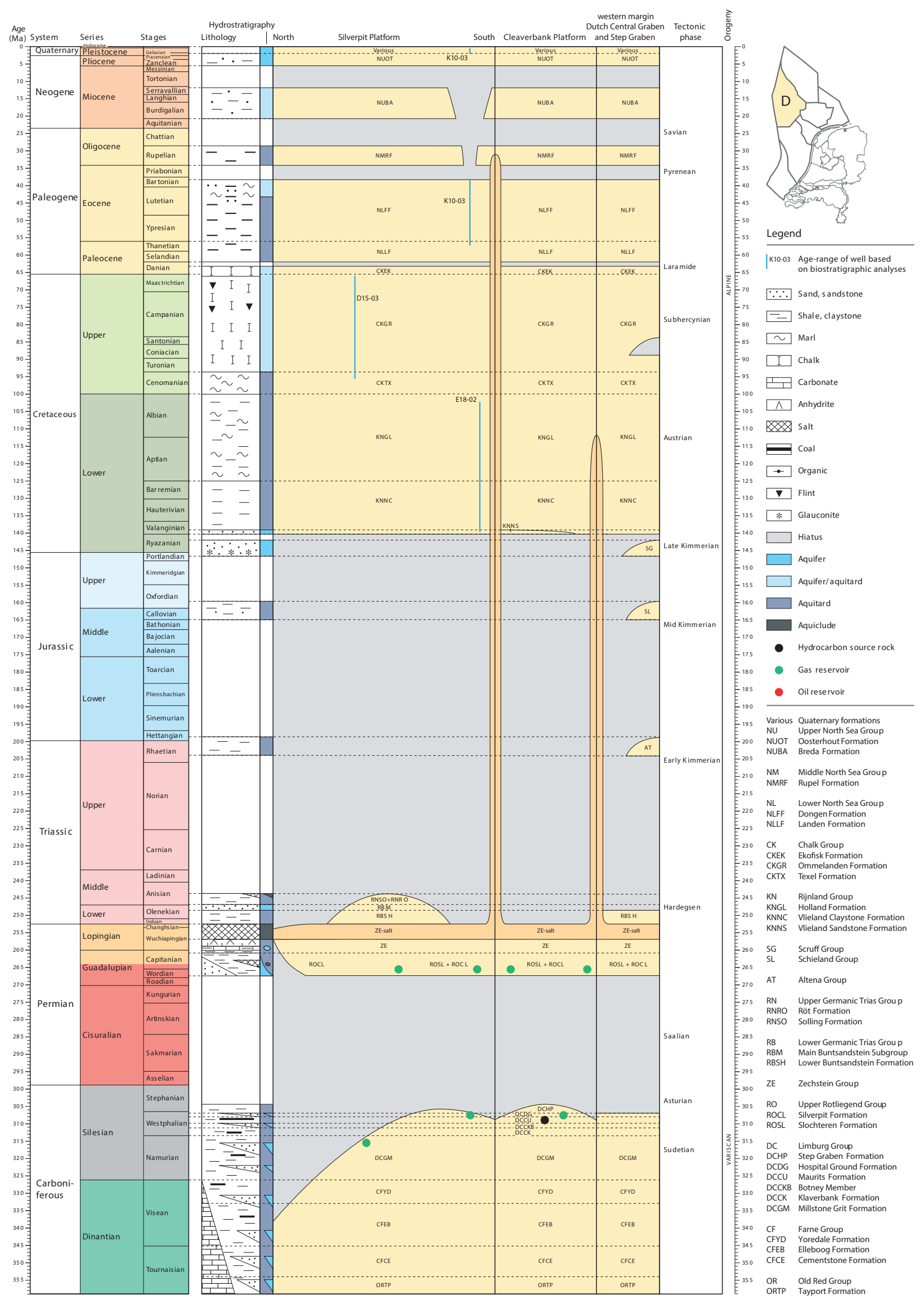

Fig. 2. Tectonostratigraphic chart of study area. Timescale and ages mostly according to Gradstein et al. (2004), except: 1) the Triassic (according to Kozur \& Bachmann (2008)); 2) the Upper Jurassic (according to Munsterman et al. (this issue)); and 3) the Quaternary (according to the International Commission on Stratigraphy (2008)). The Western European nomenclature is used for the Carboniferous series and stages. 


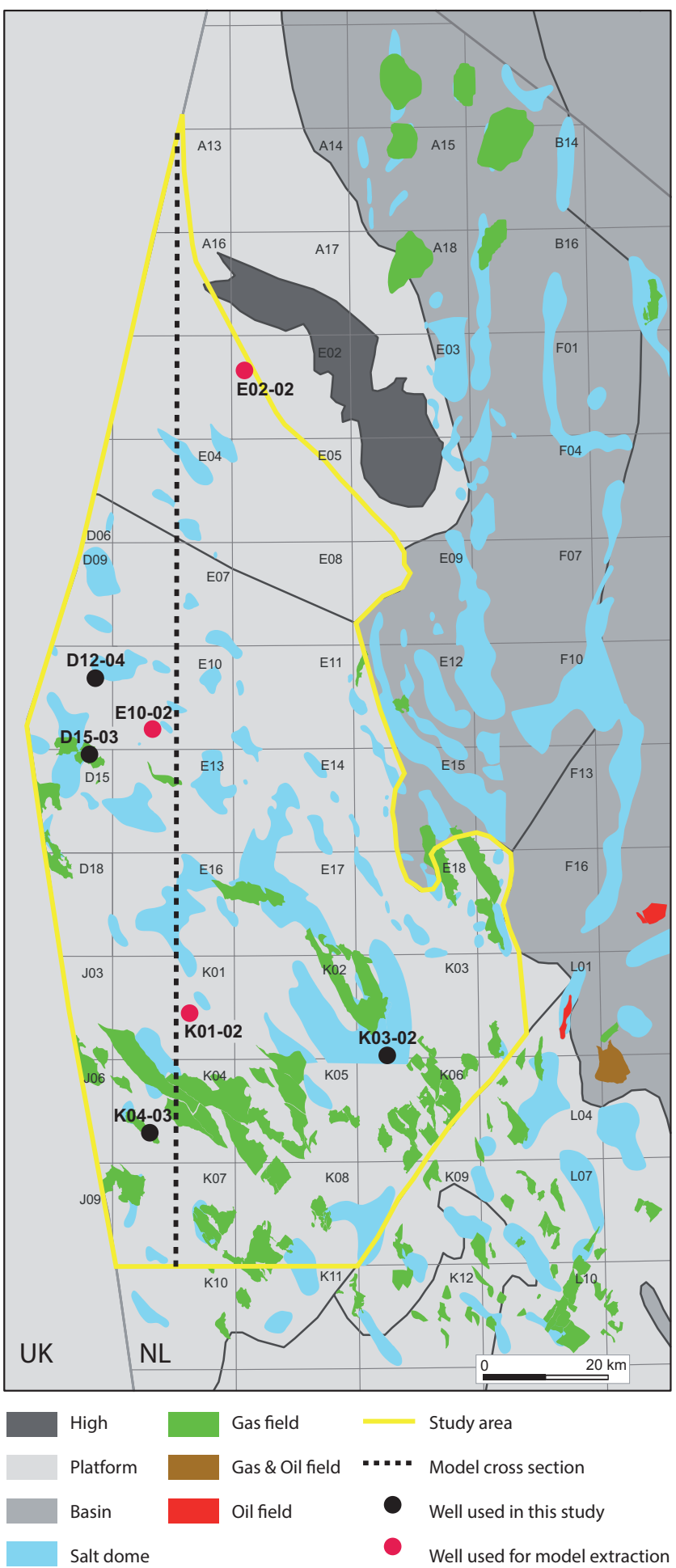

Fig. 3. Map of the study area showing the distribution of major gas fields and the major structural units. The wells used in the study are indicated. Wells used for $1 D$ extractions used for burial history, temperature and maturity analysis are given the red colour.

\section{Geological model}

The initial 3D stratigraphic model consists of 9 stratigraphic groups. These include the Upper North Sea, Lower \& Middle North Sea, Chalk, Rijnland, Schieland and Scruff, Altena, Upper
Germanic Trias, Lower Germanic Trias and Zechstein groups. New maps are created and included in the model to achieve the required level of detail. A Rotliegend thickness map is created and added to the model by interpolating between present-day thicknesses from wells over the whole area. The model is extended below the Rotliegend Group by adding Carboniferous layers. The Carboniferous section comprises five layers, the Step Graben, Hospital Ground, Maurits, Klaverbank and PreWestphalian. The Pre-Westphalian layer in the model consists of both the Namurian and Dinantian. A basement of $2000 \mathrm{~m}$ thickness is added at the base of the succession. The model is refined with additional maps for the Upper North Sea Group which is subdivided into 3 new layers; Quaternary, Pliocene and Miocene. The final refined and extended 3D model includes 17 layers plus basement (Table 1). The assigned lithology for each of the layers is based on the generalised description of the lithology as described by Van Adrichem Boogaert \& Kouwe (1993). Facies variations are taken into account for three layers; the Rotliegend, Klaverbank and Namurian formations. Facies maps for these formations are based on well observations (Table 1).

The Carboniferous section in the model is constructed based on a subcrop map of the Carboniferous formations (Fig. 4; Kombrink et al., 2010). The subcrop map is based on well and biostratigraphic data (Kombrink et al., 2010). In addition, well data and stratigraphical and palaeogeographical concepts have been used to reconstruct the depositional thicknesses of the formations. Depositional thicknesses of 300, 200 and $200 \mathrm{~m}$ are given to the Step Graben, Hospital Ground and Maurits formations respectively. The Klaverbank Formation is given a depositional thickness that varies between $1500 \mathrm{~m}$ in the south to $1000 \mathrm{~m}$ in the north of the area.

The subcrop map shows that in the northern part of the study area the Namurian (Millstone Grit Formation) and Westphalian successions are absent. The Dinantian Farne Group subcrops directly below the Upper Rotliegend Group (Fig. 4). The Namurian and the Dinantian are given depositional thicknesses of $500 \mathrm{~m}$ and $1000 \mathrm{~m}$, respectively. The thicknesses are speculative and are mainly based on regional data and palaeogeographical concepts (for example Gerling et al., 1999; Kombrink, 2008). Both layers are combined in the model in a single layer named the Pre-Westphalian with a total depositional thickness of $1500 \mathrm{~m}$. Two lithofacies are assigned to the Pre-Westphalian layer in the model. The Pre-Westphalian layer is assigned a deep marine facies in the south which reflects the Namurian facies. In the northern part of the study area, the Pre-Westphalian is assigned a fluvial and deltaic facies (cf. Gerling et al., 1999; Schroot et al., 2006; Kombrink, 2008).

Two source rock types are assigned to reflect the two facies. The northern part of the layer, where the Namurian is eroded, is defined as source rock of type III (Gerling et al., 1999; Schroot et al., 2006). The rest of the layer further south is defined as source rock type II which represents the deep-water Namurian facies (Gerling et al., 1999; Schroot et al., 2006). No information 
Table 1. Layers and assigned lithological composition used in the model. Note the facies assigned to the Rotliegend Group, the Klaverbank Formation and the Pre-Westphalian units.

\begin{tabular}{|c|c|c|c|c|c|c|}
\hline \multicolumn{2}{|c|}{ Layer } & \multicolumn{2}{|c|}{ Deposition age (Ma) } & \multicolumn{2}{|c|}{ Erosion age (Ma) } & \multirow{2}{*}{$\begin{array}{l}\text { Lithology } \\
\text { Facies } \\
\end{array}$} \\
\hline & & \multirow{2}{*}{$\begin{array}{l}\text { From } \\
2.5\end{array}$} & \multirow{2}{*}{$\begin{array}{l}\text { To } \\
0\end{array}$} & \multirow{2}{*}{$\begin{array}{l}\text { From } \\
0\end{array}$} & \multirow{2}{*}{$\begin{array}{l}\text { To } \\
0\end{array}$} & \\
\hline 1 & Quaternary & & & & & $75 \%$ Shale, $25 \%$ sand \\
\hline 2 & Pliocene & 5.33 & 2.5 & 0 & 0 & $50 \%$ Shale, $50 \%$ sand \\
\hline 3 & Miocene & 20.1 & 5.33 & 0 & 0 & $50 \%$ Shale, $50 \%$ sand \\
\hline 4 & Middle and Lower North Sea Group & 56.8 & 28 & 0 & 0 & $90 \%$ Shale, $10 \%$ sand \\
\hline 5 & Chalk & 99.1 & 61.7 & 0 & 0 & $100 \%$ Chalk \\
\hline 6 & Rijnland Group & 124 & 99.1 & 0 & 0 & $75 \%$ Shale, $25 \%$ silt \\
\hline 7 & Schieland Group & 153.87 & 140.7 & 0 & 0 & $75 \%$ Shale, $25 \%$ silt \\
\hline 8 & Altena Group & 203.7 & 173 & 173 & 170 & $75 \%$ Shale, $25 \%$ silt \\
\hline 9 & Upper Germanic Trias Group & 246.2 & 203.7 & 170 & 165 & $75 \%$ Shale, $25 \%$ silt \\
\hline 10 & Lower Germanic Trais Group & 251 & 246.2 & 165 & 153.87 & $75 \%$ Shale, $25 \%$ silt \\
\hline 11 & Zechstein Group & 258 & 251 & 0 & 0 & $100 \%$ Salt \\
\hline \multirow[t]{4}{*}{12} & Rotliegend Group & 263.99 & 258 & 0 & 0 & \\
\hline & Rotliegend Group - North & 263.99 & 258 & 0 & 0 & $90 \%$ Shale, $10 \%$ sand \\
\hline & Rotliegend Group - South & 263.99 & 258 & 0 & 0 & $95 \%$ Shale, $5 \%$ sand \\
\hline & Rotliegend Group - Middle & 263.99 & 258 & 0 & 0 & $80 \%$ Shale, $50 \%$ salt \\
\hline 13 & Step Graben & 308.7 & 307 & 305 & 300 & $50 \%$ Shale, $50 \%$ sand \\
\hline 14 & Hospital Ground & 311 & 308.7 & 300 & 290 & $50 \%$ Shale, $50 \%$ sand \\
\hline 15 & Maurits Formation & 312 & 311 & 290 & 280 & $80 \%$ Shale, $15 \%$ sand, $5 \%$ coal \\
\hline \multirow[t]{5}{*}{16} & Klaverbank Formation & 315.3 & 312 & 280 & 270 & \\
\hline & Klaverbank Formation - North & 315.3 & 312 & 280 & 270 & $80 \%$ Sand, $20 \%$ shale \\
\hline & Klaverbank Formation - South & 315.3 & 312 & 280 & 270 & $48 \%$ Shale, $25 \%$ sand, $25 \%$ silt, $2 \%$ coal \\
\hline & Pre-Westphalian & 326.5 & 315.3 & 0 & 0 & $60 \%$ Shale_40 $\%$ sand \\
\hline & Pre-Westphalian (Namurian) & 326.5 & 315.3 & 0 & 0 & $60 \%$ Shale_40\% sand \\
\hline 17 & Pre-Westphalian (Dinantian) & 326.5 & 315.3 & 0 & 0 & $50 \%$ Shale_50\% sand \\
\hline 18 & Basement & 340 & 326.5 & 0 & 0 & Basement \\
\hline
\end{tabular}

is available on the distribution and the location of the organicrich beds in the Pre-Westphalian layer. In this study we assume that the organic matter is uniformly distributed over the whole succession. The Klaverbank and Maurits coal-bearing formations of the Limburg Group are defined in the model as source rocks of kerogen type III. For the Klaverbank Formation, the properties varied following the lateral facies distribution in the area.

The original TOC and HI values used in the modelling are estimated from measured data from surrounding areas in our in-house database and published sources (e.g. Gerling et al., 1999; Van Balen et al., 2000; Pletsch et al., 2010). Source rock properties of these intervals are shown in Table 2.

Main uplift and erosion phases in the model are limited to the Saalian and Mid-Late Kimmerian events. Later events, such as the Laramide, Pyrenean and Savian, are not included because of their limited extension and intensity in the area compared to other erosion events. A number of additional non-deposition phases are included in the model as well (Table 1). The amount of eroded material is estimated for each erosional period using regional and stratigraphic information from well and seismic data (Kombrink et al., this issue).
Carboniferous deposits underwent strong uplift and erosion during the Latest Carboniferous and Early Permian (Saalian uplift). Erosional thicknesses are calculated based on the subcrop map and the assumed depositional thicknesses (Fig. 5). The platforms were uplifted again during the Late Jurassic (Mid and Late Kimmerian phase). The movement caused deep erosion and complete removal of the Lower to Middle Jurassic sediments as well as parts of the Triassic sediments. The erosion maps of the Altena Group (AT), Upper Germanic Trias Group (RN) and Lower Germanic Trias Group (RB) are calculated assuming uniform depositional thicknesses of $200 \mathrm{~m}, 400 \mathrm{~m}$ and $500 \mathrm{~m}$, respectively (Fig. 5).

\section{Boundary conditions}

Palaeo water depths (PWD) are allowed to vary in time in the study area. The PWD curve is compiled based on literature as well as detailed investigation by the Geobiology department at TNO for some specific intervals. The palaeo water depths are kept constant over the entire area for each time interval (Fig. 6). The palaeo temperature at the sediment water interface (SWIT) 


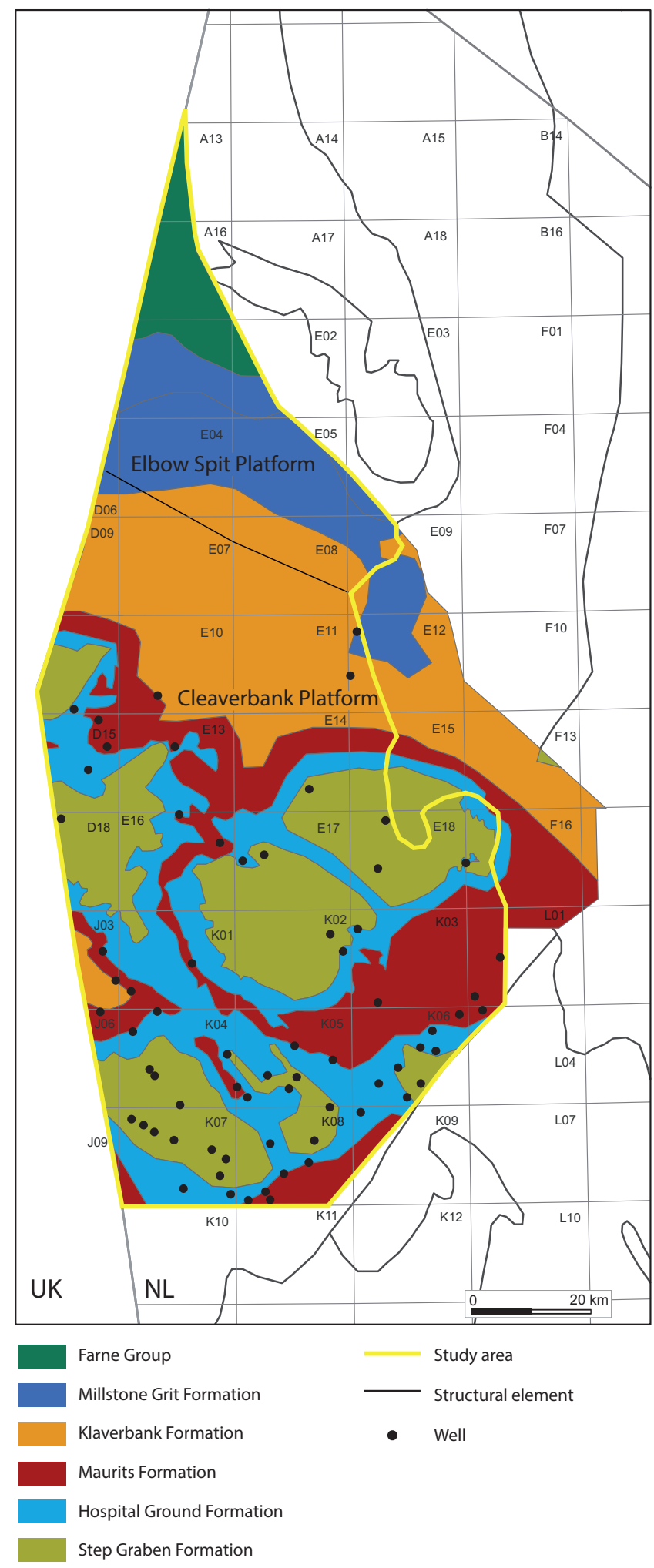

Fig. 4. Subcrop map of the Carboniferous formations in the NCP-2D area (modified after Kombrink et al., 2010).

is calculated with an integrated PetroMod tool that takes into account the palaeo water depth and the evolution of ocean surface temperatures through time depending on palaeolatitude of the area. For the Cenozoic and Quaternary more detailed temperature boundary conditions are reconstructed.
Table 2. Average source rock parameters used for simulating timing of hydrocarbon generation.

\begin{tabular}{llll}
\hline Source rock & $\begin{array}{l}\text { Kerogen } \\
\text { type }\end{array}$ & $\begin{array}{l}\text { TOC } \\
\text { (wt \%) }\end{array}$ & $\begin{array}{l}\text { HI } \\
\text { (mg HC/g T0C) }\end{array}$ \\
\hline Maurits & Type III & 4 & 200 \\
Klaverbank-North & Type III & 1 & 100 \\
Klaverbank-South & Type III & 3 & 100 \\
Pre- Westphalian - North & Type III & 2 & 200 \\
(Dinantian) & & & \\
Pre-Westphalian - South & Type II & 2 & 200 \\
(Namurian) & & & \\
\hline
\end{tabular}

This is done in order to take into account the effect of Cenozoic warming and cooling fluctuations on source rock maturity and hydrocarbon generation in the studied region (Verweij et al., 2012). Basal heat flow is modelled using the 1D tectonic heat flow modelling tool PetroProb (Van Wees et al., 2009). The tool uses the sedimentation, uplift and erosion history for single wells to predict the evolution of the basal heat flow in that well. PetroProb takes into account the tectonic evolution of the basin and requires a user-defined model of the lithosphere. Basal heat flow histories are constructed at two well locations to generate heat flow maps for the whole area for all stages (Wells E10-02 and K01-02; Abdul Fattah et al., 2012a).

Tectonic subsidence is calculated from the decompacted burial history at the wells. The observed tectonic subsidence is inverted and a best-fit tectonic model is found which is used to predict the basal heat flow. Uncertainties in the input parameters are taken into account during the calculations and as a result the modelled heat flows are expressed in a probabilistic way. The models are calibrated to measured temperatures and vitrinite reflectance data from the well (Van Wees et al., 2009). The heat flow model that gives the best fit is selected. The Saalian tectonic phase is identified in the model as a thermal uplifting event followed by thermal relaxation that provided accommodation space in Late Permian times (Van Wees et al., 2000). Therefore, a non-uniform tectonic model is adopted where the sub-crustal lithosphere undergoes more stretching than the crustal lithosphere which remains stable (Van Wees et al., 2009). For the Mid-Late Kimmerian phase, the tectonic model assumes a thermal doming associated with crustal stretching. A non-uniform tectonic model is adopted which counts for a crustal stretching (extensional settings) as well as thermal uplift and underplating that resulted in erosion (Abdul Fattah et al., 2012a).

Modelling results suggest that the thermal uplift and underplating during the Saalian and the Mid-Late Kimmerian erosion phases have resulted in a peak in the basal heat flow (Fig. 7). The Mid-Late Kimmerian (Mid-Late Jurassic) uplift is associated0 with a peak in basal heat flow reaching $77 \mathrm{~mW} / \mathrm{m}^{2}$ in $\mathrm{E} 10-02$ and $70 \mathrm{~mW} / \mathrm{m}^{2}$ in $\mathrm{K} 01-02$. This difference in the heat 

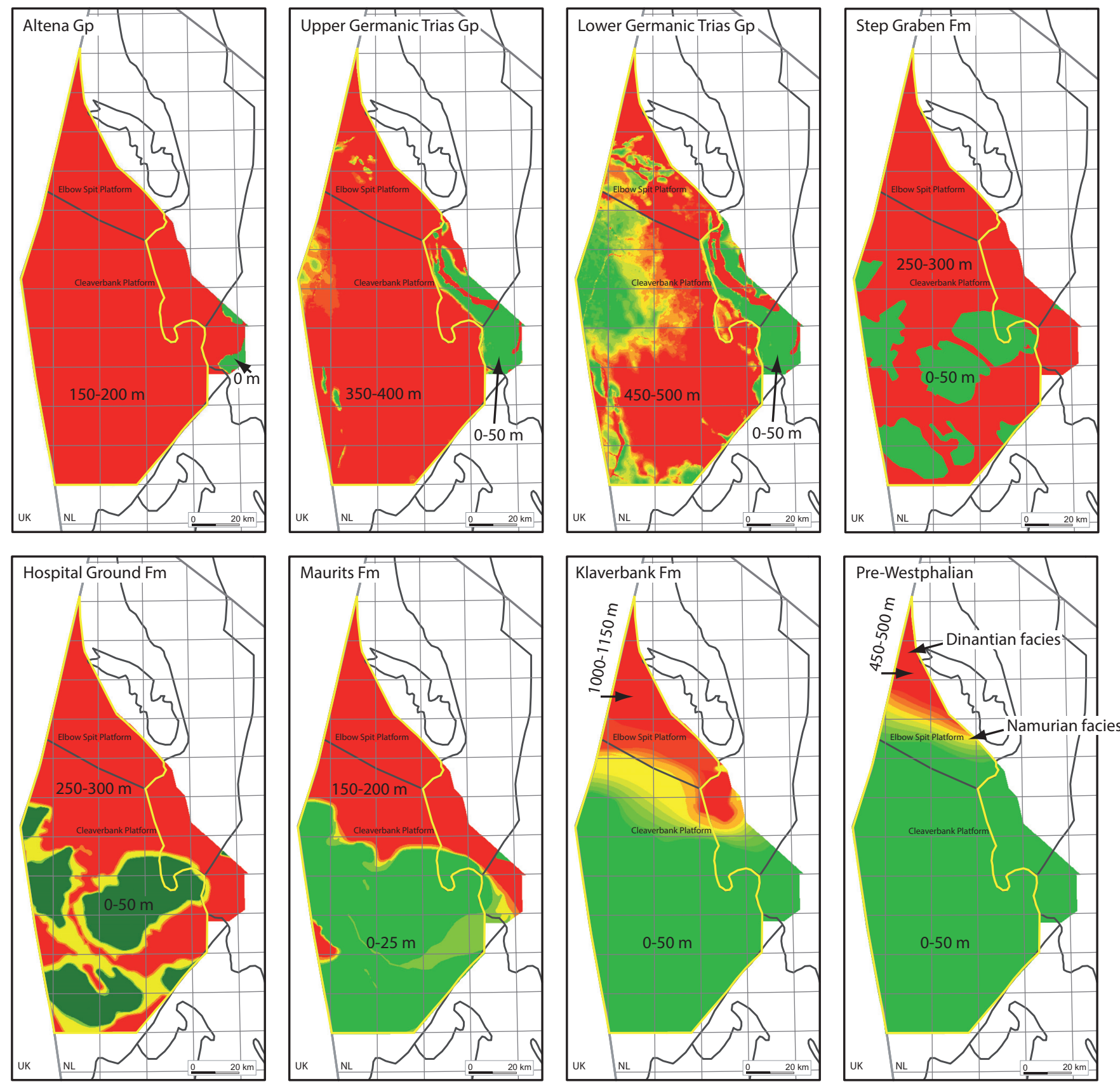

Fig. 5. Erosion maps of the main eroded units in the study area as introduced to the model.

flow can be attributed to differences in tectonic history, burial evolution and stratigraphic succession in both wells (Abdul Fattah et al., 2012a). The present-day basal heat flow is at its minimum, reaching values of $55-60 \mathrm{~mW} / \mathrm{m} 2$ with slightly higher values in the Cleaverbank Platform (well E10-02).

\section{Default set-ups, assumptions and calibration}

Default simulation set-ups concern the lithologies of the different formations and their associated properties. These properties include thermal conductivity, radiogenic heat production, heat capacity as well as mechanical compaction equations and porosity-permeability relations. Thermal conductivity values are defined based on a pre-defined thermal conductivity model (the Sekiguchi Model; PetroMod 11). The radiogenic heat production is calculated for the rock matrices for each of the lithologies. The compaction model is based on the Hydrostatic Athy's law Model where the porosity versus depth curve is a theoretical curve that assumes a hydrostatic pressure and a uniform lithological column. Measured porosities and permeabilities provided the basis for selecting the proper compaction and porosity-permeability relations.

Temperature and vitrinite reflectance data are used to calibrate the $1 \mathrm{D}$ and later the $3 \mathrm{D}$ input model. The maturity modelling is based on the Sweeney \& Burnham (1990) kinetic model. The calculations of the transformation ratios for the 

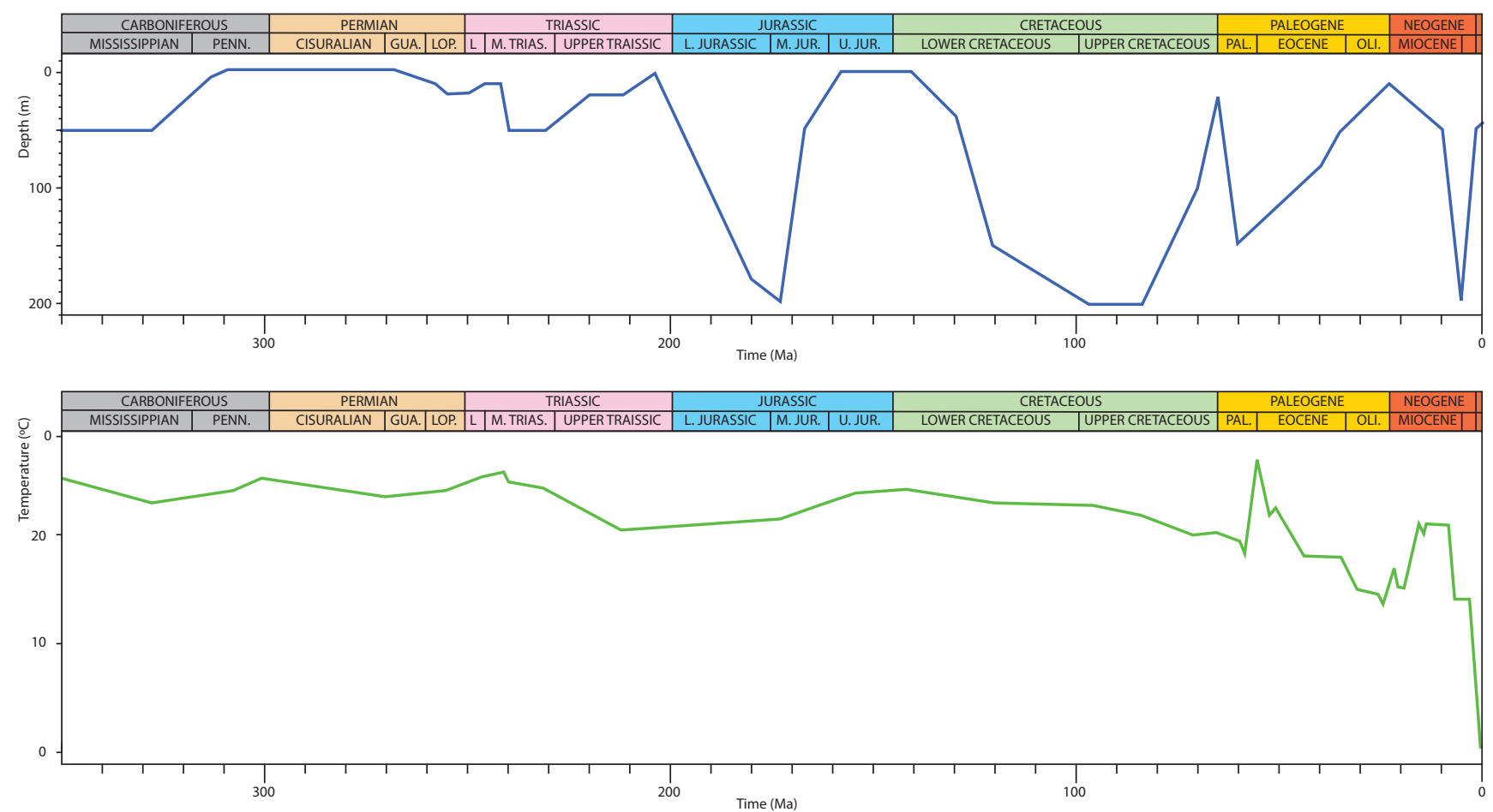

Fig. 6. Detailed Palaeo Water Depth (PWD) curve (top) and detailed Palaeo Sediment Water Interface Temperature (SWIT) curve (bottom).
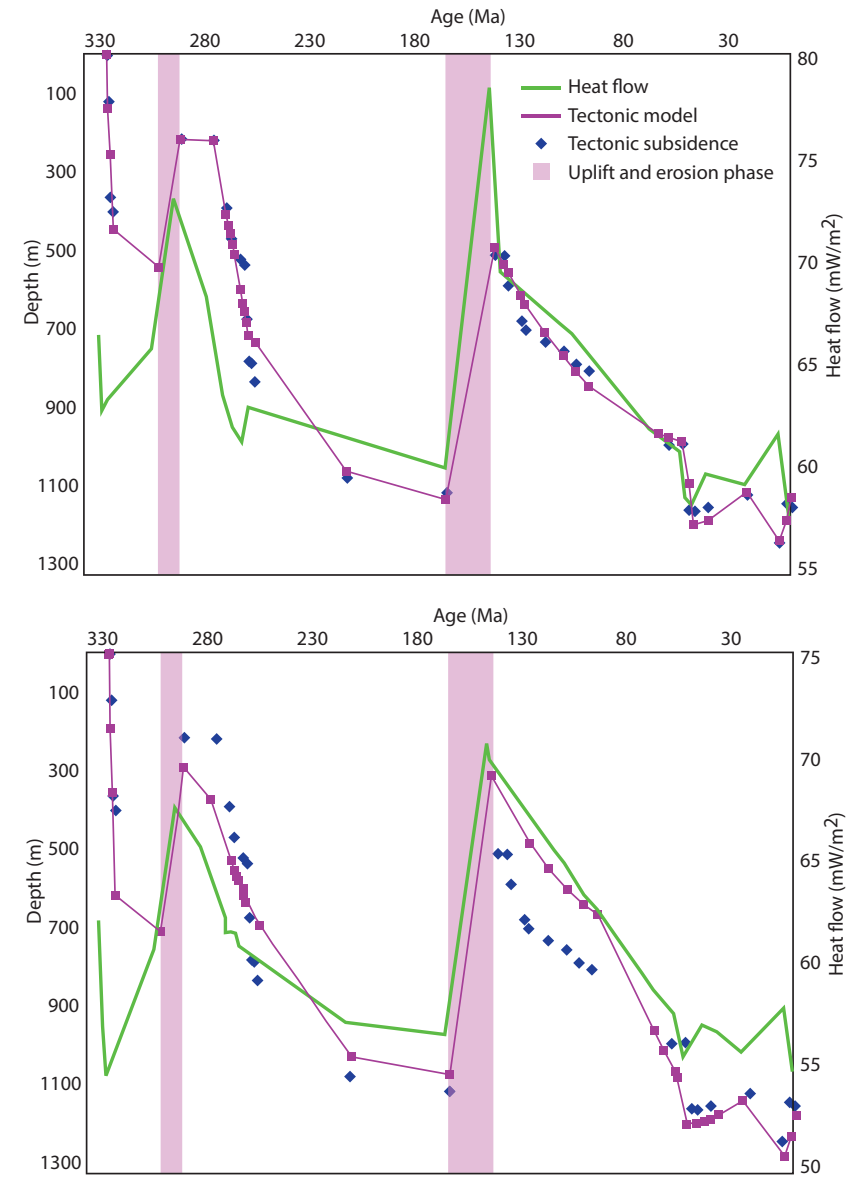

Fig. 7. Basement heat flow modelled in PetroProb and calibrated with measured data at well E10-02 (top) and well K01-02 (bottom). Both observed and modelled tectonic subsidence are also shown together with the main two uplift and erosion phases. For the location of the wells see Fig. 3. assigned source rock intervals are based on the Pepper \& Corvi (1995) TII and TIII hydrocarbon generation kinetics. The implemented generation kinetics depend on the facies assigned. The Pepper \& Corvi (1995) TII kinetic model is used for the southern and central part of the Pre-Westphalian layer (the Namurian facies). The Pepper \& Corvi (1995) TIII is used for the Westphalian formations (Maurits and Klaverbank) and the northern part of the Pre-Westphalian layer (Dinantian).

The initial geological model does not include faults and assumes open fluid flow boundaries. The 3D simulations of temperature and maturity are run assuming hydrostatic conditions and only conductive heat flow is assumed in the model. Salt movement and, as a consequence, the thermal effect related to it are not considered in the modelling. The presentday thickness distribution of the Zechstein Formation in the platform area does not indicate strong salt tectonics.

\section{Results}

\section{Burial history}

The burial history as well as temperature and maturity history are discussed using representative $1 \mathrm{D}$ extractions of the $3 \mathrm{D}$ model at the location of three wells; E10-02 and K01-02 located on the Cleaverbank Platform, and well E02-02 located on the Elbow Spit Platform (Fig. 3).

The burial history (Fig. 8) shows two phases of rapid subsidence and sedimentation in the two platforms; during the Late Carboniferous and Late Permian-Early Triassic ( 270-245 Ma). Two uplift phases include the Early Permian and Mid-Late Jurassic 
( 170-150 Ma; the Mid-Late Kimmerian phase). The area remains uplifted from the Late Jurassic until the Early Cretaceous and starts to subside gently during the Mid Cretaceous. These burial histories are similar to other platforms in the vicinity (e.g. De Jager, 2003, 2007; Verweij et al., 2009, 2010). The burial history shows that the area has reached maximum burial at presentday. The northern Elbow Spit Platform has undergone less burial than the rest of the area (well E02-02; Fig. 8). The burial depth of Carboniferous source rocks on the Elbow Spit Platform at presentday is similar to the burial depth in Mid Jurassic times (Fig. 8).
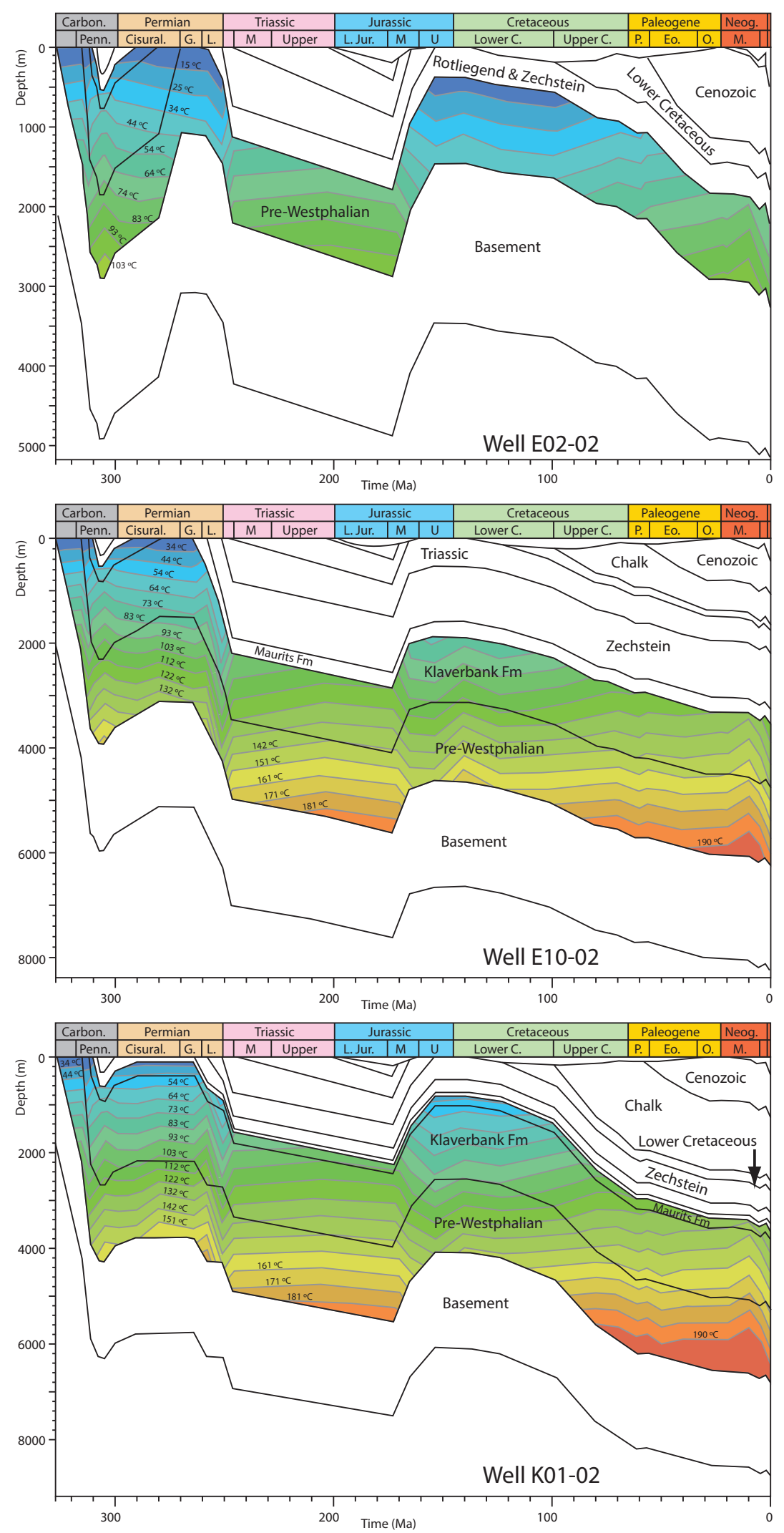

Fig. 8. The burial history of three $1 D$ extractions from the 3D model. The simulated temperature evolution for the major source rock units is plotted on top of the burial histories of the thee well extractions. Location of the extractions is indicated in Fig. 3. 


\section{Thermal history}

Modelled present-day temperatures in wells E10-02 and K01-02 show a good fit with measured temperatures (Fig. 9a). Figure 8 shows the modelled temperature evolution of the source rock intervals for the selected wells. The simulation results show lower temperatures in the northern part of the study area (well E02-02) compared to wells K01-02 and E10-02 (Fig. 8). The simulated temperature history shows two major heating peaks at wells E10-02 and K01-02. The first maximum temperature in the Carboniferous units was reached during the Early Jurassic (prior to the Kimmerian uplift phase). The Pre-Westphalian succession reached a temperature up to $200^{\circ} \mathrm{C}$ in deeper parts and the temperature of the overlying Carboniferous Klaverbank and Maurits Formations ranged between $120^{\circ} \mathrm{C}$ to $160^{\circ} \mathrm{C}$. During the Late Jurassic and Early Cretaceous, the temperatures of the formations decreased as a result of Kimmerian uplift. The second high temperature phase is reached at present-day in the entire platform area. The present-day temperatures in the Namurian peak around $200^{\circ} \mathrm{C}$ while they vary between $130^{\circ} \mathrm{C}$ to $170^{\circ} \mathrm{C}$ in the Klaverbank and Maurits Formations (Fig. 8). In well E02-02, the temperature of the Pre-Westphalian layer varied between $110^{\circ} \mathrm{C}$ to $130^{\circ} \mathrm{C}$ during the Late Jurassic-Early Cretaceous and has similar values at present-day. The simulation results indicate an additional temperature peak during the Late Carboniferous. The layer reached a temperature of around $130^{\circ} \mathrm{C}$ prior to Saalian uplift and erosion (Fig. 8).

\section{Maturation history}

Modelled present-day maturity (vitrinite reflectance) at the location of the wells is presented in Fig. 9b. The modelled maturity is in a good agreement with measured values. Modelled maturity history (vitrinite reflectance) and the hydrocarbon zones of Carboniferous source rocks at the location of the three 1D extractions are shown in Fig. 10. The maturity history indicates that the deepest parts of the assigned source rock units entered the hydrocarbon generation ranges already in the Carboniferous. The maturity increased during the Triassic and reached a peak in Early Jurassic and prior to the Late Kimmerian uplift ( 170 Ma). The central part of the Cleaverbank Platform (wells K01-02 and E10-02) reached its maximum maturity at present-day. The Pre-Westphalian in this part of the study area reached the overmature state already in the Late Triassic (Fig. 10).

\section{Hydrocarbon generation history}

The modelled hydrocarbon zones are shown in Fig. 10. Despite the increase in maturity, the Pre-Westphalian layer did not enter the hydrocarbon generation zone in the northern part of the Elbow Spit Platform (well E02-02). In other parts of the study area, the Pre-Westphalian started hydrocarbon generation during the Late Carboniferous. While upper parts of the layer were generating oil, the lower parts were generating gas. In the Permian, the deepest parts of the Pre-Westphalian were already overmature. By the Triassic, only the upper parts of the PreWestphalian in the majority of the platform area were able to produce gas. The Pre-Westphalian reached the overmature state in the end of the Triassic (Fig. 10). Maturity history shows that the deeper parts of the Klaverbank Formation started oil generation in the Triassic. Most of the layer entered the gas window at the onset of the Paleogene (Fig. 10). The model indicates that the Maurits Formation started hydrocarbon generation in the Paleogene (Fig. 10).

A number of variations in the degree of present-day maturity are observed over the study area (Fig. 11). While the
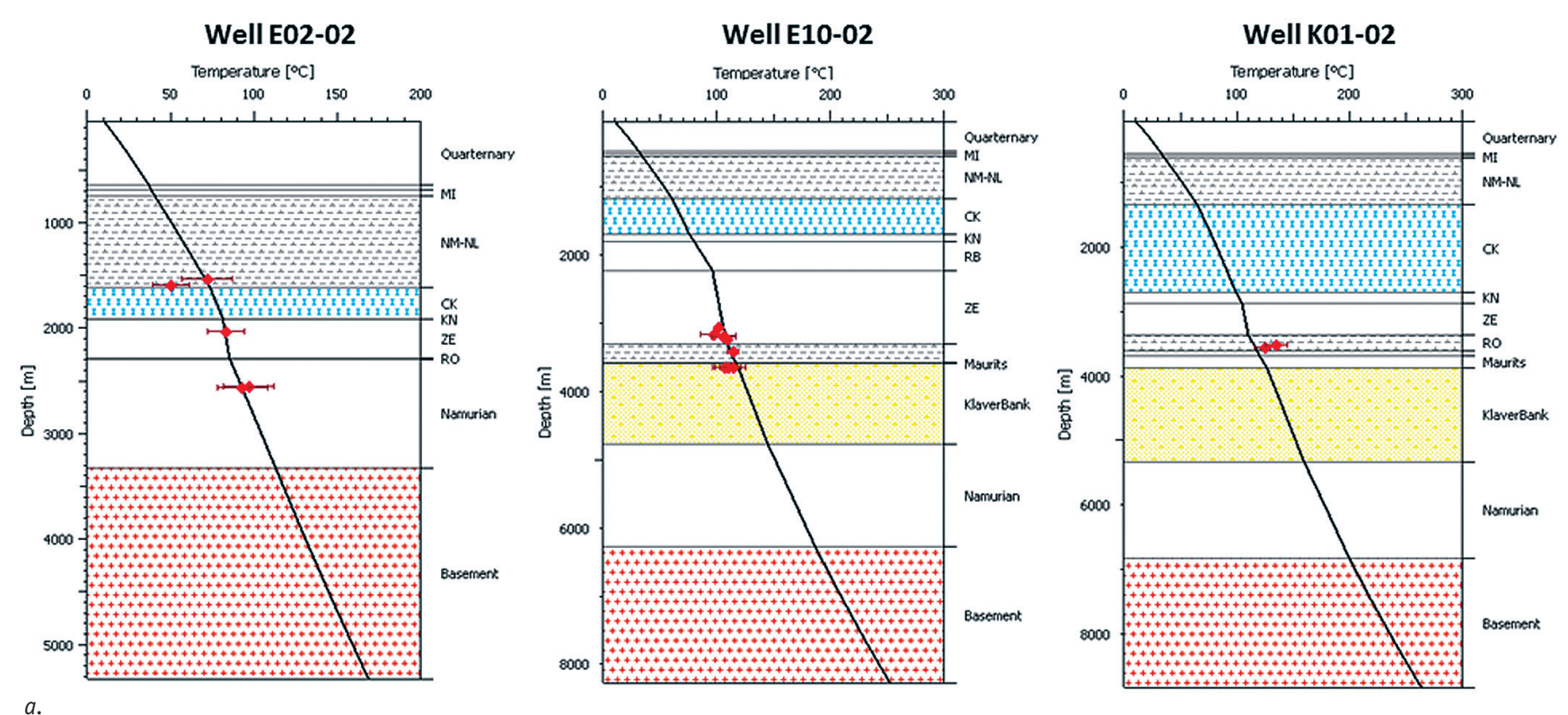

Fig. 9a. Modelled present-day temperatures. 

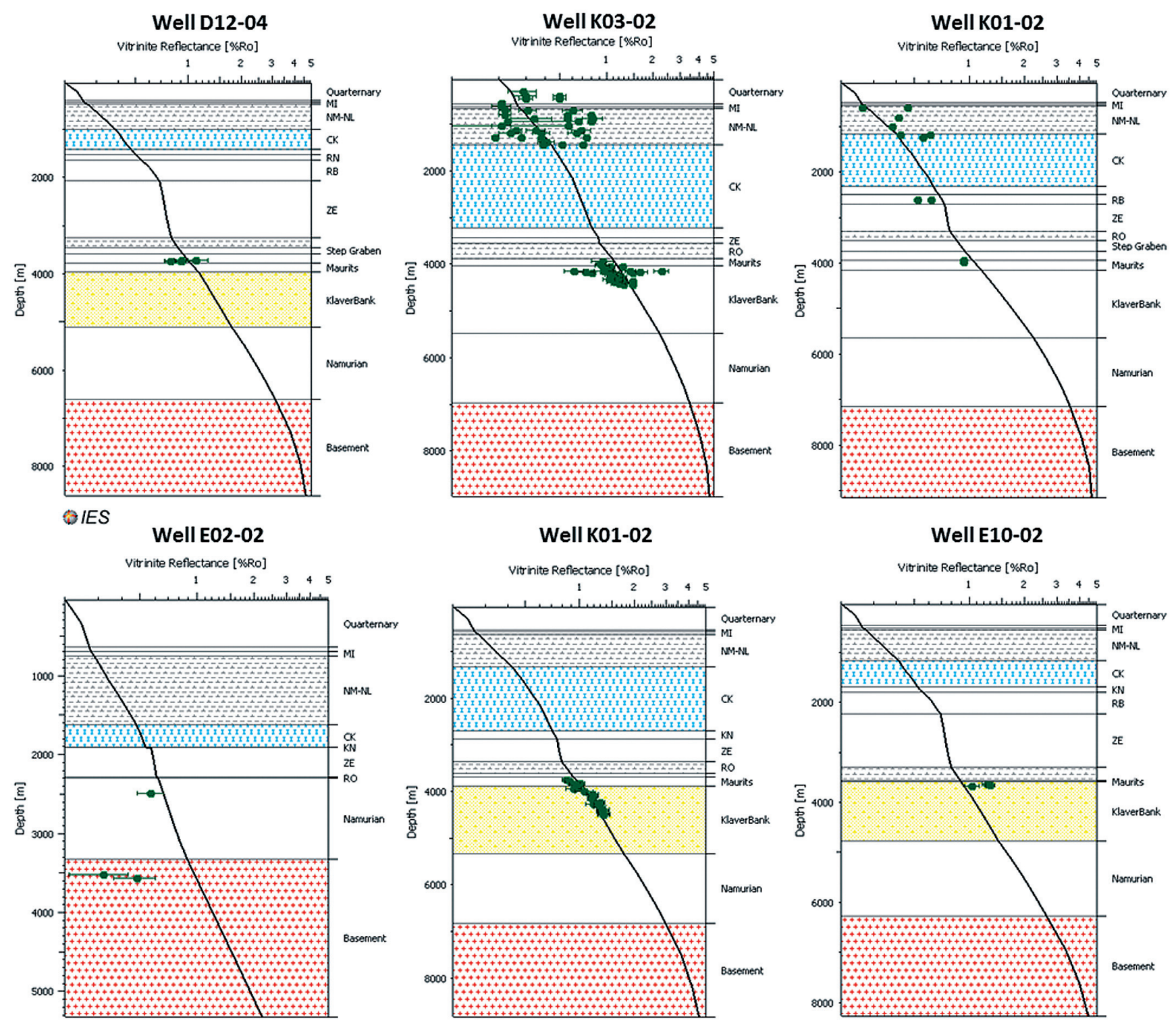

Well K01-02

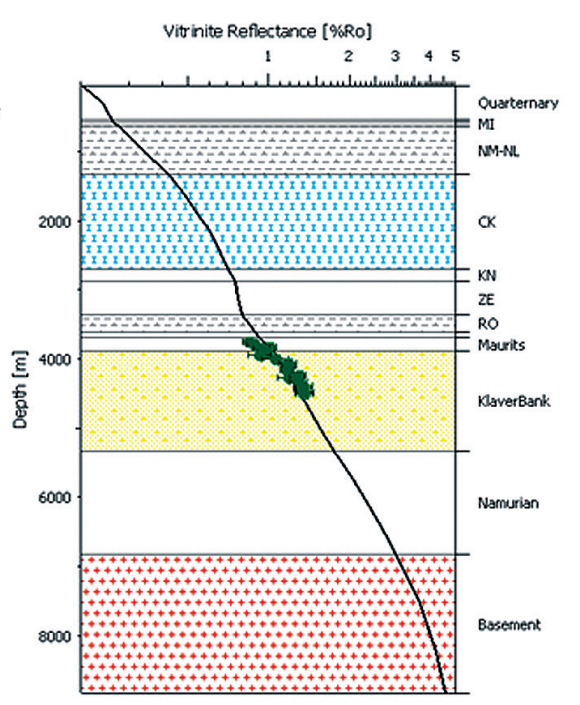

Fig. 9b. maturity values (vitrinite reflectance) in a selection of wells in the study area. Location of the wells is shown in Fig. 3.

Pre-Westphalian is immature in the northern part, it appears to be overmature in the central and southern parts of the study area. Only the northern parts of the Cleaverbank and the Elbow Spit platforms are still in oil and gas windows (Fig. 11). The Klaverbank Formation is in the gas window in most of the study area. The formation is immature in the western parts of the Elbow Spit Platform and the northern parts of Silverpit Platform. It has reached the overmature state in the central part of the Cleaverbank Platform (Fig. 11). The Maurits Formation appears to be in the gas window in the Cleaverbank Platform. It is still immature in parts of the Cleaverbank Platform to the west (Fig. 11).

The transformation ratio is another indicator of hydrocarbon generation. It is the ratio of generated petroleum to the original petroleum potential in a source rock. The transformation ratio provides information on the timing of hydrocarbon generation and is calculated for the source rock units. The 

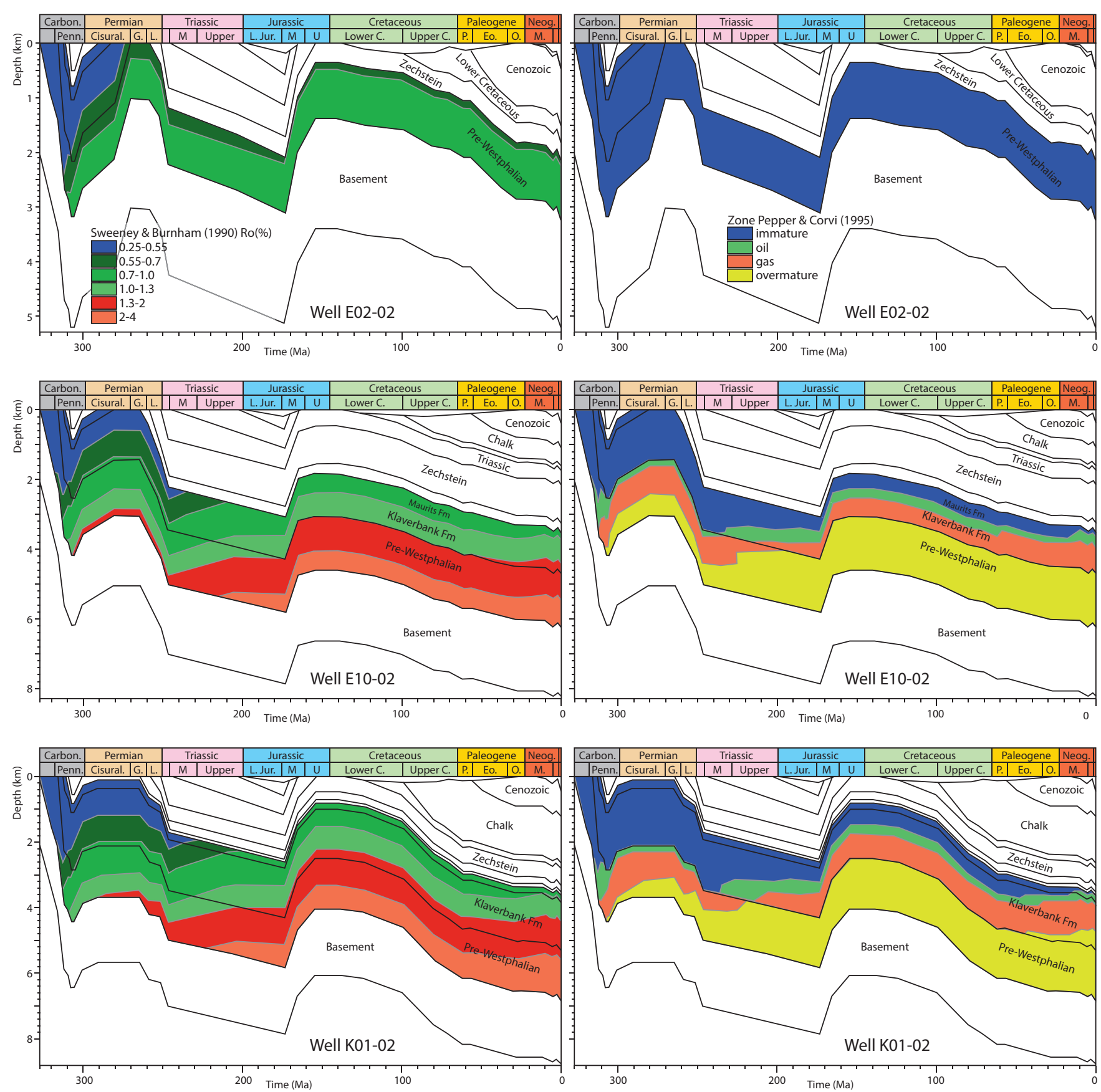

Fig. 10. Modelled maturity (left) and hydrocarbon generation (right) history for the major source rock units in thee well extractions. The modelled hydrocarbon generation is based on the applied generation kinetics for each source rock (Pepper \& Corvi, 1995 TIII, TII).

calculation of the transformation ratios is based on the Pepper and Corvi (1995) TII and TIII kinetic models. Figure 12 shows the transformation ratio (TR-All \%) of the three Carboniferous source rocks at the location of five 1D extractions (Fig. 3). A remarkable difference is observed in the transformation ratio of the Pre-Westphalian layer between the northern part and the rest of the study area. The model indicates that only a small amount of the transformable organic material is converted to hydrocarbons at well E02-02. In all other wells, however, almost all the organic material is converted to hydrocarbons at presentday (Fig. 12). In all of these wells, a jump in the transformation ratio took place in the Late Carboniferous. About $90 \%$ of the organic material in the Pre-Westphalian layer was transformed by the end of the Triassic.

The history of the transformation ratio of the Klaverbank Formation shows more variations over the area. In places, hydrocarbon generation within the Klaverbank Formation started during Early Triassic and reached a first peak in Mid Jurassic (Fig. 12). The magnitude of the transformation ratio varies significantly. In well K04-02, almost $25 \%$ of the organic material in the Klaverbank was transformed by the Mid Jurassic. This percentage did not exceed $10 \%$ in the other wells. Starting 

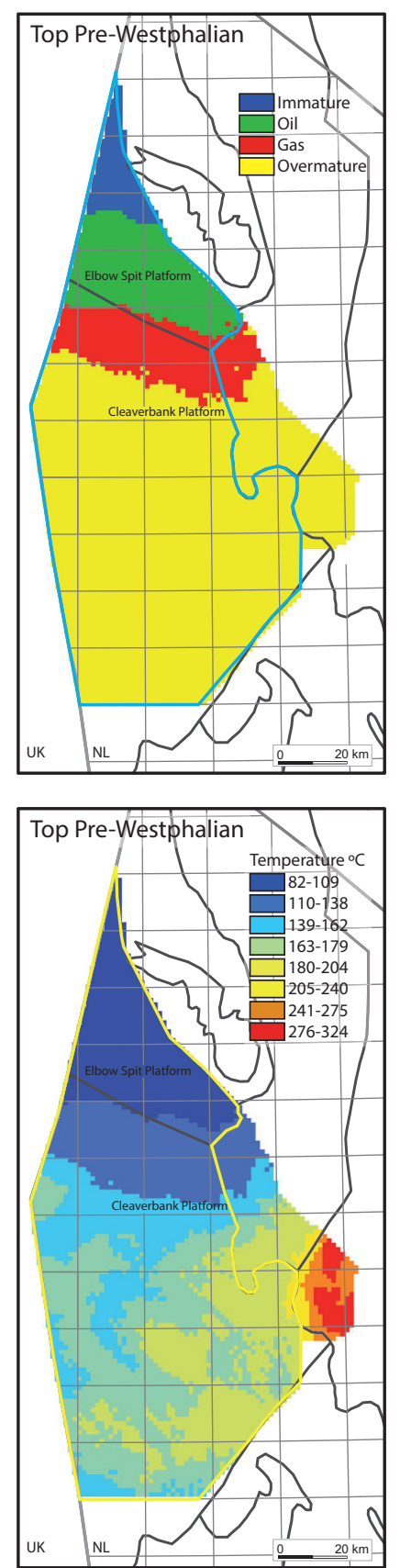

Corvi, 1995 TIII, TII).
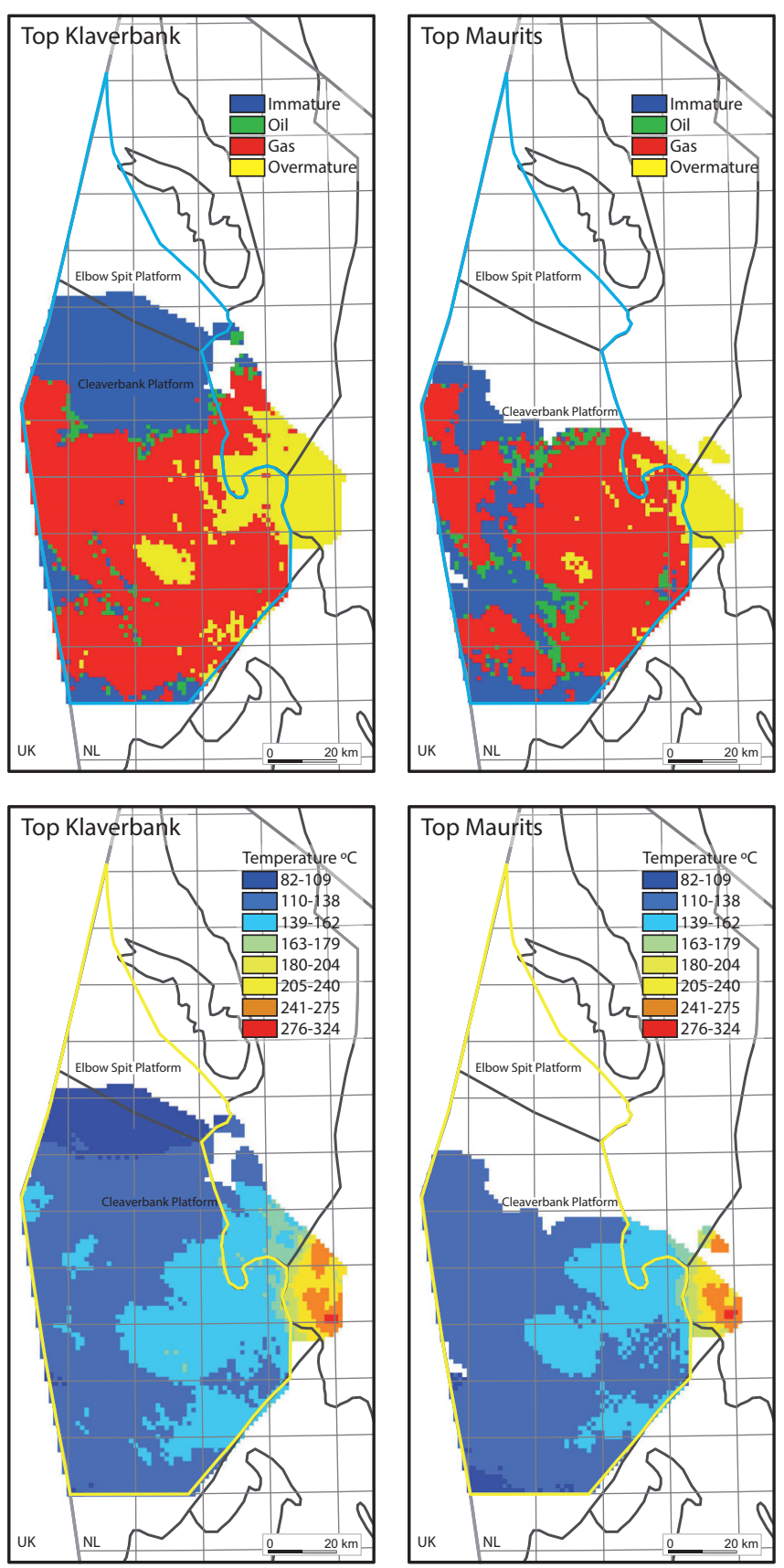

from the Late Cretaceous, the Klaverbank Formation resumed hydrocarbon generation with varying rates depending on the location. The highest ratio is observed in the wells $\mathrm{K} 03-02$ and K04-03 (ca. 60\% and 58\% respectively) on the Cleaverbank Platform (Fig. 12). Towards the north, the transformation ratio is lower and reaches a value of ca 15\% in well E10-02. An increase in the transformation ratio took place during the Miocene. This is apparent in all the $1 \mathrm{D}$ extractions from the study area.

Hydrocarbon generation in the Maurits Formation started during the Late Cretaceous-Early Paleogene in the whole area and reached a maximum value today. Transformation ratios vary over the area with the highest values observed in well K04-03 and well K03-02 (ca. 25\%). Similar to the Klaverbank Formation, the transformation ratio in the Maurits Formation decreases northwards. An increase is observed during the Miocene over the whole area (Fig. 12).

\section{Discussion}

\section{Input, assumptions and conditions}

The outcome of basin modelling is dependent on the input data and the uncertainties involved. A number of assumptions and default set-ups have been introduced to the model. The distribution and thickness of the Carboniferous formations, and especially the Pre-Westphalian succession, is a major source of uncertainty in the model. The thickness and distribution of the Carboniferous layers were estimated from the base Permian 

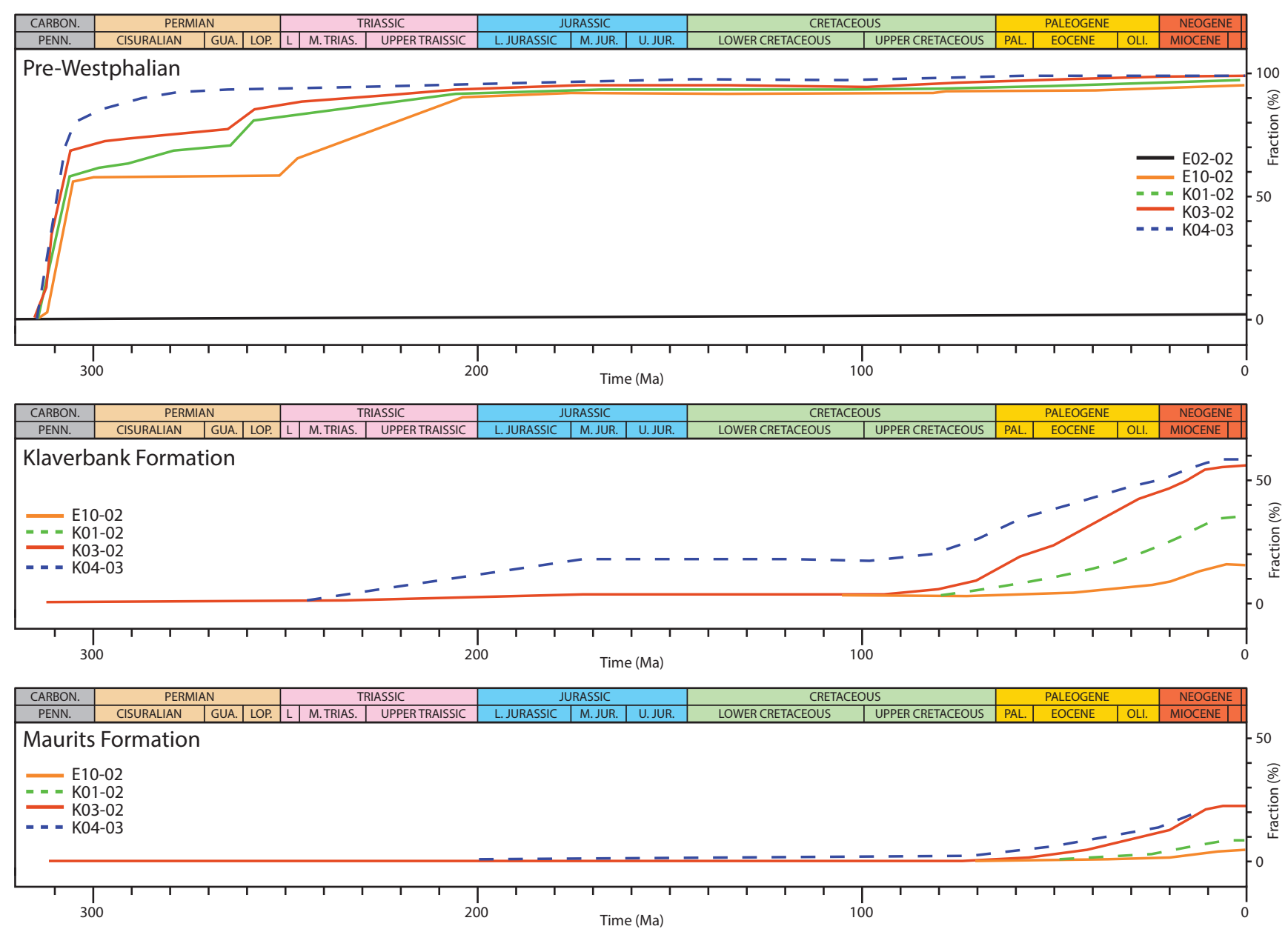

Fig. 12. History of transformation ratio of the major Carboniferous source rocks in five 1D extractions. For the location of the extractions see Fig. 3.

subcrop map, well and regional information. The actual presence, location and properties of the source horizons in the PreWestphalian in the study area are as yet largely unknown. In the simulations we used a scenario where the entire PreWestphalian succession, which comprises the Namurian and Dinantian, is a source rock.

\section{Calibration}

The modelled temperatures in two wells (E10-02 and K01-02) show a good fit with well measurements (Fig. 9a). The fit suggests that the combination of the heat flow and the thermal conductivity of the major lithologies is acceptable. Moreover, a good fit is achieved between modelled vitrinite reflectance and the measured values in a selection of wells (Fig. 9b).

\section{Modelling results}

\section{Burial history}

The 1D burial histories indicate that deepest burial in most of the area is at present-day. In the north, the current burial depth of the source rocks is approximately the same as during the
Jurassic and prior to the Mid-Late Kimmerian uplift phase (Figs 8 and 10). The model also shows that in the northern part of the study area (well E02-02; Fig. 8) deep burial takes place during the Late Carboniferous. Therefore, maturity is sensitive to the total erosion during the Saalian event in this area. The modelled maturities show a good fit with the measurements (Fig. 9a). This indicates that the total thicknesses eroded during the Kimmerian uplift are not likely to be higher than the values used in the model.

\section{Temperature history}

An increase in temperature and therefore maturation can be achieved either by deep burial or higher heat flow. Our modelling results show that the burial effect in the study area has been more important than heat flow peak related to the Mid-Jurassic rifting event. The models show that maximum temperatures are reached when the layers are at deepest burial (Figs 7 and 8). 


\section{History of maturity and $\mathrm{HC}$ generation}

Source rocks in the Pre-Westphalian succession in the centre and the south of the study area were almost completely transformed into hydrocarbons by the Early Jurassic (Figs 10, 11 and
12). This is because the Upper Carboniferous succession has not completely been eroded during Saalian uplift. Maturity models for the Namurian in adjacent areas show similar patterns (Schroot et al., 2006). Abdul Fattah et al. (2012b) have shown that the Namurian in the inverted Broad Fourteens and the
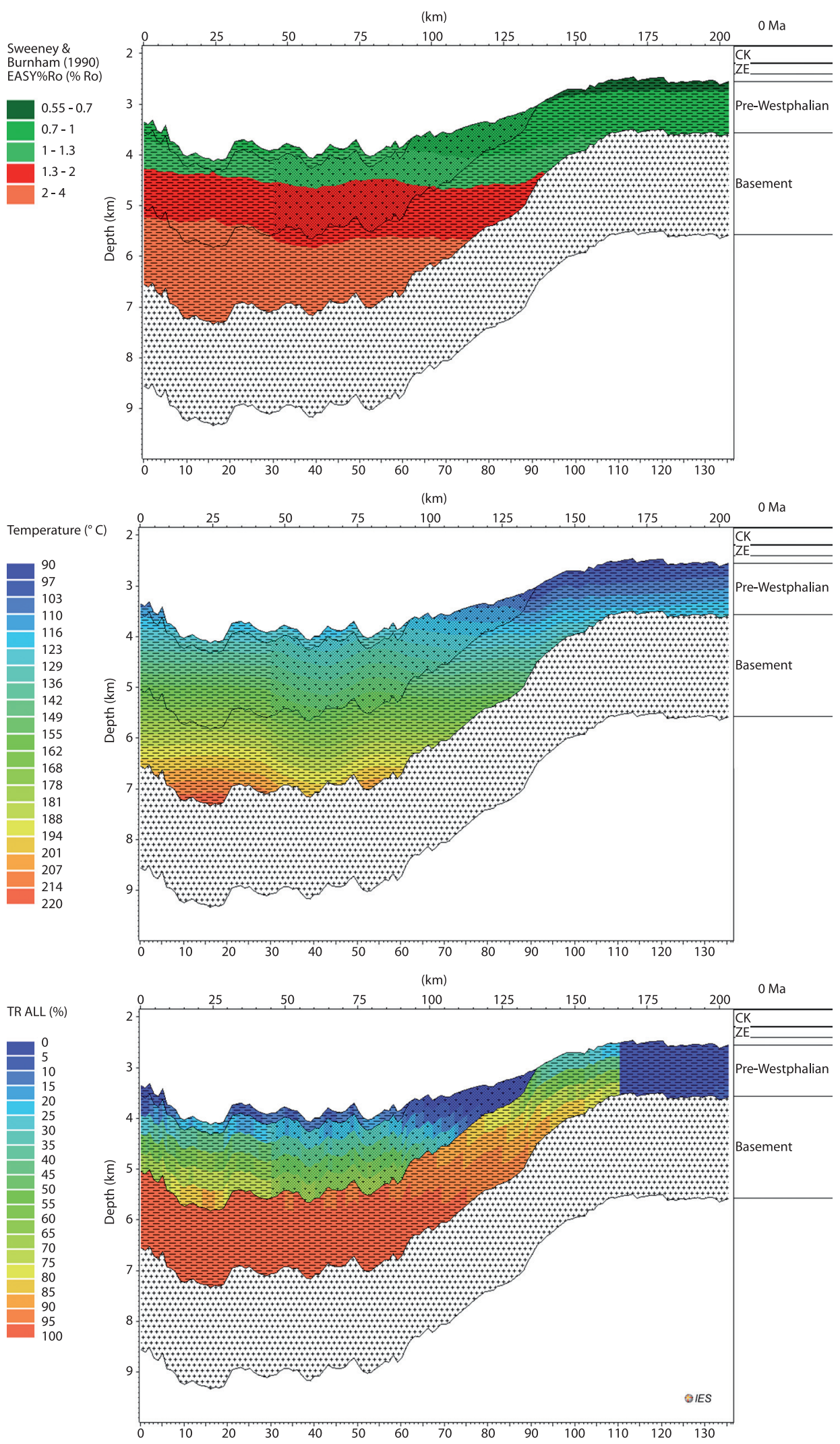

Fig. 13. Cross-section showing the modelled maturity (top) transformation ratio (middle) and temperature (bottom) of the Pre-Westphalian and Westphalian formations. Maturity decreases northwards where burial depth is lower. The low transformation ratio of the Pre-Westphalian layer in the north is because of the assigned facies and type of organic matter (kerogen III). Location of the cross section is shown in Fig. 3. 
West Netherlands basins are overmature. The Namurian in these basins started to produce hydrocarbons already in the Late Carboniferous and reached an overmature state in the Jurassic.

In the northern part of the study area the original thickness of the overlying formations is less and the degree of uplift and erosion was more pronounced. Therefore, the Pre-Westphalian succession shows a low maturity in the range of 0.5 to $0.7 \%$ Ro which implies an immature to early mature gas prone source rock (Fig. 11). The calculated transformation ratio from the area (well E02-02) indicates very low hydrocarbon generation rates (Figs 11 and 12). Comparable maturity ranges have been reported by Schroot et al. (2006) for the Top Dinantian in the south-western parts of the Elbow Spit Platform.

In addition to the burial history, the differences in maturity of the Pre-Westphalian can be explained by differences in the type of organic material and the applied hydrocarbon generation kinetic model. In the centre and south of the study area, the Pre-Westphalian succession is assigned a Namurian marine facies with organic matter of kerogen type II. In the north, where the Namurian is eroded, the Pre-Westphalian (Dinantian) succession shows a fluvial and deltaic facies with organic matter of kerogen type III. The applied generation kinetics for kerogen type III results in relatively low transformation of the organic matter and hydrocarbon generation even when relatively high temperatures values are reached (Figs 8, 10, 12 and 13).

Maturity and transformation ratio simulation results show that the Westphalian formations are generally in the gas generating phase and even overmature in places (Figs 11 and 12). The maturity variations over the area can be attributed to differences in the burial of the Westphalian formations rather than to thermal anomalies or increased geothermal gradients.

The simulated transformation ratio of the Namurian shows that almost all of the organic matter was transformed to hydrocarbons by the end of Triassic-Early Jurassic. Although deeper burial and higher temperatures were reached later, limited amount of organic matter was left to produce gas in the Namurian after the Triassic. This implies that if the gas in the current fields was charged from Namurian source rocks, it must have been preserved for 200 million years and was not affected by (mainly) inversion events. Further research including simulation of hydrocarbon migration, charging and preservation is needed to assess the likelihood of preservation of Namuriansourced gas accumulations in Carboniferous and Upper Rotliegend reservoirs in the area.

The modelled transformation ratios of the Klaverbank and Maurits formations suggest that the main phase of hydrocarbon generation took place during the Cenozoic (Fig. 12). Both Westphalian formations are expected to produce hydrocarbons until today. These Westphalian-derived gases are therefore a likely source for the gas fields in the area.

Based on gas sample analyses, Gerling et al. (1999) argue that the accumulated gas is a mixture of terrestrial and marine source rocks that can either be Namurian or Dinantian shales.
Considering the outcome of this study, the conclusion of Gerling et al. (1999) can be explained be one of the following scenarios. Firstly, an early trapping of hydrocarbons occurred already in Late Triassic - Early Jurassic. This would also imply the preservation of the traps since the trapping time. Secondly, recent generation of some hydrocarbons from the pre-Westphalian has taken place. Finally, a mixed source of gas could be explained by the presence of some marine organic matter in the Westphalian source rocks. Assessing these possibilities would require a detailed basin modelling study that cover hydrocarbon migration and charging as well as quantitative analyses of hydrocarbon generation.

\section{Nitrogen}

Nitrogen $\left(\mathrm{N}_{2}\right)$ is the most abundant non-hydrocarbon gas component encountered in the accumulations of natural gas in the Netherlands. In the offshore area, gas analyses from Rotliegend as well as Carboniferous fields in the K, J, D and E blocks show relatively high concentrations of nitrogen (Fig. 14; NLOG database www.nlog.nl). The possible origin of the nitrogen in the gas accumulations in North Western Europe has been subject of many studies (Littke et al. 1995; Gerling et al. 1997; Krooss et al. 1995, 2005, 2006; Mingram et al., 2003, 2005; Verweij, 2008). Although the source of nitrogen is still not very well understood, the organic material in the Westphalian coals can be an important contributor. Ammonium fixed in Namurian shales is another possible source of nitrogen.

Organic nitrogen is liberated from coal during maturation of the kerogen (early nitrogen phase) prior to the main gas generating phase (De Jager \& Geluk, 2007). Considering the maturity, the Klaverbank and Maurits formations may locally still be in the early nitrogen phase. Early nitrogen might therefore have been generated during the Cenozoic where the Westphalian started to generate gas (Fig. 12). It is also possible that some early nitrogen is generated prior to the Cenozoic gas generation. Pre-Westphalian strata and the deepest parts of the Westphalian formations are thought to be a possible source of (late) nitrogen. Late nitrogen is formed in the final stage of gas generation after methane generation has practically ceased (e.g. Krooss, 1995). Krooss et al. (2005) suggest that the organic matter can act as a nitrogen source up to a maturity level of $4 \%$ Vr. Depending on the temperatures and timing of late nitrogen generation, this might have contributed to nitrogen accumulation in the gas reservoirs (Gerling et al., 1999; De Jager \& Geluk, 2007).

The release of non-organic nitrogen from shales requires relatively high temperatures $\left(200-250^{\circ} \mathrm{C}\right.$; Mingram et al., 2003; Krooss et al., 2006; Verweij, 2006). Our model indicates that the Pre-Westphalian succession has reached temperatures between $150-220^{\circ} \mathrm{C}$ (Figs 8, 11 and 13). These temperatures might have led to the release of nitrogen from Namurian or Dinantian strata. Volcanism might have contributed to the liberation of 


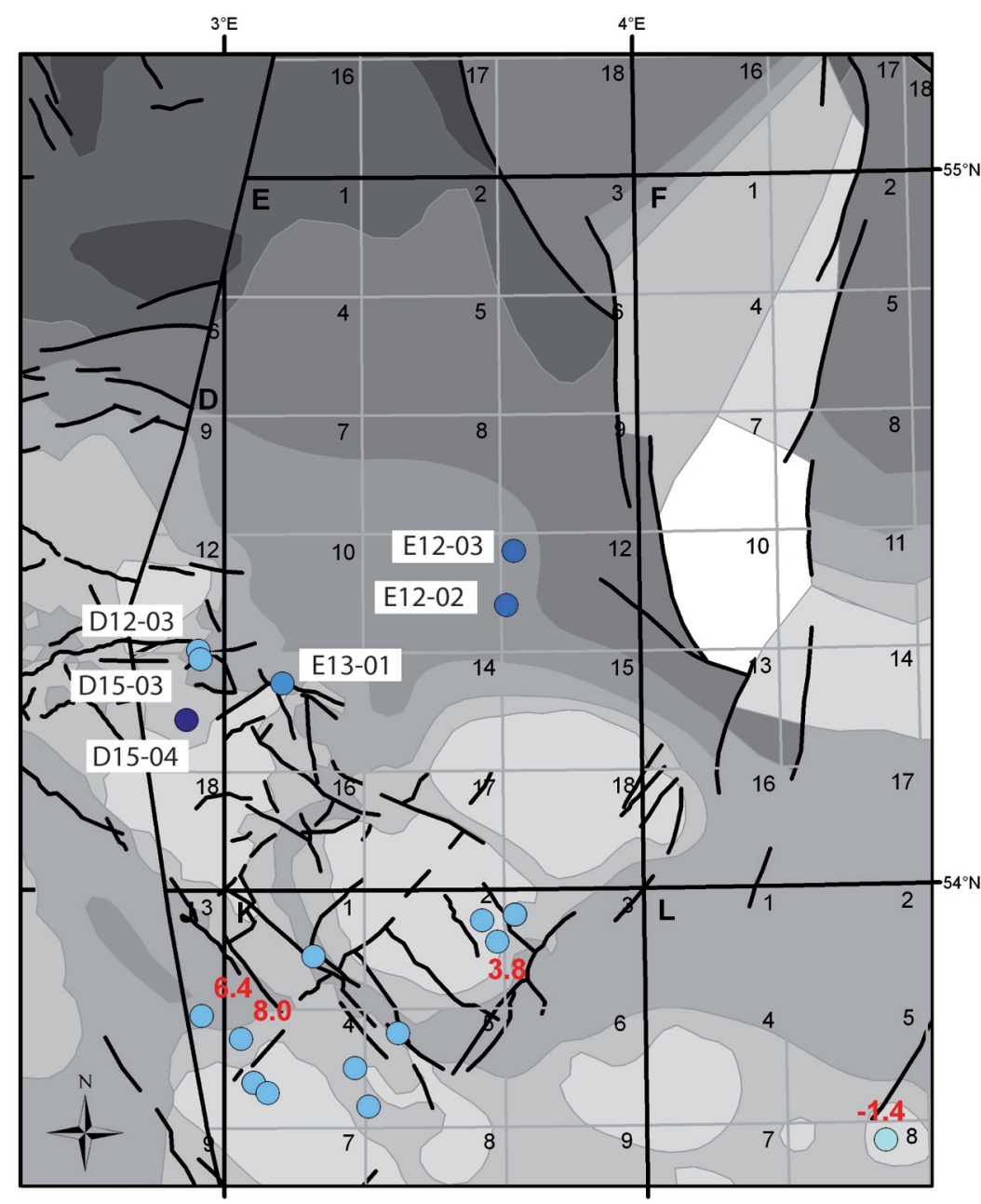

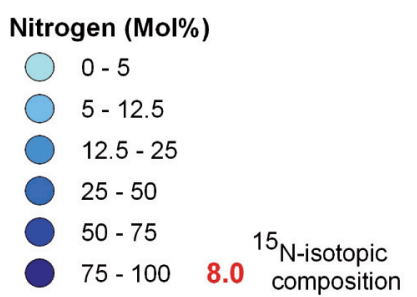

Subcrop at base Permian
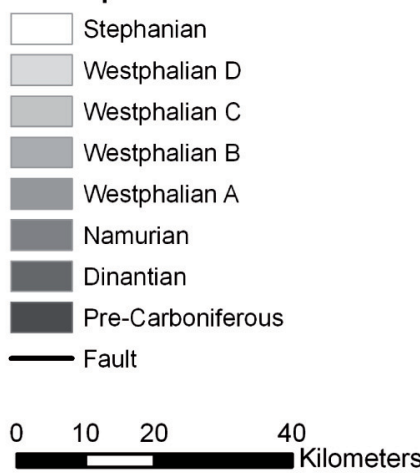

Fig. 14. Variation in nitrogen content in gas accumulations in Carboniferous rocks (from Kombrink et al., 2009). nitrogen due to local temperature anomalies. Igneous rocks were found in a number of wells in the E block in the study area (Sissingh, 2004; Van Bergen \& Sissingh, 2007).

After all, it is difficult to attribute the nitrogen concentrations in the gas fields to a specific source. The contribution of Westphalian coal seams (early nitrogen phase) is likely to be present, but not easy to distinguish from late nitrogen whether organic or non-organic. More studies are needed in order to specify different sources of nitrogen in the gas fields. For this purpose, isotope analysis of nitrogen can help segregating different nitrogen groups and identifying their sources (Littke et al., 1995, 2005; Gerling et al., 1997; Krooss et al., 1995, 2005, 2006; Verweij, 2006, 2008).

\section{Conclusions}

In this study, recently compiled data from the main platforms in the northwestern part of the Dutch offshore (Cleaverbank and Elbow Spit Platforms) are used for a full 3D reconstruction of the burial and temperature history, source rock maturity and timing of hydrocarbon generation. The study focused on Carboniferous source rocks.

New boundary condition parameters are used in the modelling workflow. Basal heat flow is calculated in two wells in the area based on tectonic models. Newly refined sediment water interface temperatures (SWIT) are used for maturity and temperature modelling. A recently updated and refined palaeo water depth (PWD) curve is implemented in the simulation. New erosion thicknesses are reconstructed for the main erosion phases based on recently compiled data.

The 3D modelling results reveal remarkable variations in maturity and hydrocarbon generation history between Westphalian and Pre-Westphalian source rocks. The PreWestphalian source rocks started hydrocarbon generation in Late Carboniferous times. In the southern and central parts of the study area, gas was generated from the Namurian until the Early Jurassic. In the major part of the study area, the PreWestphalian was overmature by Late Triassic times. The maturity of the Pre-Westphalian decreases toward the north. The Pre-Westphalian (Dinantian) source rock in the north is still immature.

The Westphalian source rocks entered the hydrocarbon generating window during the Late Triassic and Early Jurassic. Maturity and hydrocarbon generation increased during the Palaeogene because of continuous burial. Most of the Maurits and Klaverbank formations are in the gas generation window. Westphalian formations are still capable of hydrocarbon generation today. Because of the late and continuous generation, 
Westphalian coal seams are likely to have had the most significant contribution to the known gas fields, rather than Namurian or Dinantian source rocks.

The simulation of temperature, maturity and hydrocarbon generation for the Carboniferous indicate that there may be different sources explaining the occurrence of nitrogen in the gas accumulations in the area. Early nitrogen may have been co-generated prior or during the Cenozoic phase of gas generation in the Westphalian source rocks. In addition, the assumed Namurian source rock reached high temperatures and maturities corresponding to a late stage of nitrogen generation before the Kimmerian tectonic uplift phase. The temperatures reached during that time and later were also high enough to allow the release of non-organic nitrogen from Namurian shales. The effect of volcanic activity is probably local.

\section{Acknowledgements}

We thank Schlumberger-IES for making it possible to use the basin modelling package (PetroMod Vr.11) for this study. The valuable comments of the Petra David (Wintershall) and Henk Kombrink (Total) on the manuscript are very much appreciated.

\section{References}

Abdul Fattah, R., Verweij, J.M., Witmans, N. \& Ten Veen, J.H., 2012a. Reconstruction of burial history, temperature, source rock maturity and hydrocarbon generation for the NCP-2D area, Dutch Offshore. TN0 - Geological Survey of the Netherlands (Utrecht). Report number TN0-034-UT-2010-0223.

Abdul Fattah, R., Verweij, J.M. \& Ten Veen, J.H., 2012b. 4D Basin modelling of the Broad Fourteens Basin and offshore West Netherlands Basin; Erosion and heat flow reconstruction and its influence on temperature, maturity and hydrocarbon generation. TNO - Geological Survey of the Netherlands (Utrecht). Report number TN0 2012 R10670.

De Jager, J., 2003. Inverted basins in the Netherlands, similarities and differences. Netherlands Journal of Geosciences 82: 355-366.

De Jager, J., 2007. Geological development. In: Wong, T.E., Batjes, D.A.J. \& De Jager, J. (eds): Geology of the Netherlands. Royal Netherlands Academy of Arts and Sciences (KNAW) (Amsterdam): 5-26.

De Jager, J. \& Geluk, M.C., 2007. Petroleum geology. In: Wong, T.E., Batjes, D.A.J. \& De Jager, J. (eds): Geology of the Netherlands. Royal Netherlands Academy of Arts and Sciences (KNAW) (Amsterdam): 241-264.

Doornenbal, J.C. \& Stevenson, A.G. (eds), 2010. Petroleum Geological Atlas of the Southern Permian Basin Area. EAGE Publications b.v. (Houten), 342 pp.

Duin, E.J.T., Doornenbal, J.C., Rijkers, R.H.B., Verbeek, J.W. \& Wong, T.E., 2006. Subsurface structure of the Netherlands; results of recent onshore and offshore mapping. Netherlands Journal of Geosciences 85: 245-276.

Gerling, P., Geluk, M.C., Kockel, F., Lokhorst, A., Lott, G.K. \& Nicholson, R.A., 1999. NW European Gas Atlas - new implications for the Carboniferous gas plays in the western part of the Southern Permian Basin. In: Fleet, A.J. \& Boldy, S.A.R. (eds): Petroleum Geology of North-West Europe: Proceedings of the $5^{\text {th }}$ Conference. The Geological Society (London): 799-808.
Gerling, P., Idiz, E., Everlien, G. \& Sohns, E., 1997. New aspects on the origin of nitrogen in natural gas in northern Germany. Geologisches Jahrbuch D103: 65-84.

Gradstein, F.M., Ogg, J.G. \& Smith, A.G., 2004. A Geologic Time Scale 2004. Cambridge University Press (Cambridge), 589 pp.

International Commission on Stratigraphy (ICS), 2008. International Stratigraphic Chart. Cambridge University Press, 184 pp.

Kombrink, H., 2008. The Carboniferous of the Netherlands and surrounding areas; a basin analysis. PhD thesis, Utrecht University (Utrecht), $184 \mathrm{pp}$.

Kombrink, H., Besly, B., Collinson, J.D., Den Hartog Jager, D.G., Drozdzewski, G., Dusar, M., Hoth, P., Pagnier, H.J.M., Stemmerik, L., Waksmundzka, M.I. \& Wrede, V., 2010. Carboniferous. In: Doornenbal, J.C. \& Stevenson, A.G. (eds): Petroleum Geological Atlas of the Southern Permian Basin Area. EAGE Publications b.v. (Houten): 81-99.

Kombrink, H., Della Lunga, D., Mijnlieff, H. \& Kroon, I., 2009. Nitrogen contents in the northwest Netherlands offshore. TNO-NITG (Utrecht; www.nlog.nl).

Kombrink, H., Doornenbal, J.C., Duin, E.J.T., Den Dulk, M., Van Gessel, S.F., Ten Veen, J.H. \& Witmans, N., 2012. New insights into the geological structure of the Netherlands; results of a detailed mapping project. Netherlands Journal of Geosciences 91-4: 419-446, this issue.

Kozur, H.W. \& Bachmann, G.H., 2008. Updated correlation of the Germanic Triassic with the Tethyan scale and assigned numeric ages. Berichte der Geologischen Bundesanstalt 76: 53-58.

Krooss, B., Jurisch, A. \& Plessen, B., 2006. Investigation of the fate of nitrogen in Palaeozoic shales of the Central European Basin. Journal of Geochemical Exploration 89: 191-194.

Krooss, B.M., Friberg, L., Gensterblum, Y., Hollenstein, J., Prinz, D. \& Littke, R., 2005. Investigation of the pyrolytic liberation of molecular nitrogen from Palaeozoic sedimentary rocks. International Journal of Earth Sciences 94: 1023-1038.

Krooss, B.M., Littke, R., Müller, B., Frielingsdorf, J., Schwochau, K. \& Idiz, E.F., 1995. Generation of nitrogen and methane from sedimentary organic matter: implications on the dynamics of natural gas accumulations. Chemical Geology 126: 291-318.

Littke, R., Krooss, B., Idiz, E. \& Frielingsdorf, J., 1995. Molecular nitrogen in natural gas accumulations: Generation from sedimentary organic matter at high temperatures. American Association of Petroleum Geologists Bulletin 79: 410-430.

Mingram, B., Hoth, P. \& Harlov, D.E., 2003. Nitrogen potential of Namurian shales in the North German Basin. Journal of Geochemical Exploration 78-79: 405-408.

Mingram, B., Hoth, P., Lüders, V. \& Harlov, D., 2005. The significance of fixed ammonium in Palaeozoic sediments for the generation of nitrogen-rich natural gases in the North German Basin. International Journal of Earth Sciences 94: 1010-1022.

Munsterman, D.K., Verreussel, R.M.C.H., Mijnlieff, H.F., Witmans, N., KerstholtBoegehold, S. \& Abbink, O.A., 2012. Revision and update of the CallovianRyazanian Stratigraphic Nomenclature in the northern Dutch offshore, i.e. Central Graben Subgroup and Scruff Group. Netherlands Journal of Geosciences 91-4: 555-590, this issue.

Pepper, A.S. \& Corvi, P.J., 1995. Simple kinetic models of petroleum formation. Part III: modelling an open system. Marine and Petroleum Geology 12: 417-452. 
Pletsch, T., Appel, J., Botor, D., Clayton, C.J., Duin, E.J.T., Faber, E., Górecki, W., Kombrink, H., Kosakowski, P., Kuper, G., Kus, J., Lutz, R., Mathiesen, A., Ostertag-Henning, C., Papiernek, B. \& Van Bergen, F., 2010. Petroleum Generation and Migration. In: Doornenbal, J.C. \& Stevenson, A.G. (eds): Petroleum Geological Atlas of the Southern Permian Basin Area. EAGE Publications b.v. (Houten): 225-253.

Quirk, D.G., 1993. Interpreting the Upper Carboniferous of the Dutch Cleaver Bank High. In: Parker, J.R. (ed.): Petroleum Geology of North-West Europe: Proceedings of the $4^{\text {th }}$ Conference. The Geological Society (London): 697-706.

Schroot, B.M., Van Bergen, F., Abbink, O.A., David, P., Van Eijs, R. \& Veld, H., 2006. Hydrocarbon potential of the Pre-Westphalian in the Netherlands onand offshore - report of the PetroPlay project. TNO Built Environment and Geosciences (Utrecht). Report number NITG-05-155-C, 436 pp.

Sekiguchi, K., 1984. A method for determining terrestrial heat flow in oil basinal areas. Tectonophysics 103: 67-79.

Sissingh, W., 2004. Palaeozoic and Mesozoic igneous activity in the Netherlands; a tectonomagmatic review. Netherlands Journal of Geosciences 83: 113-134.

Sweeney, J.J. \& Burnham, A.K., 1990. Evaluation of a simple model of vitrinite reflectance based on chemical kinetics. American Association of Petroleum Geologists Bulletin 74: 1559-1570.

TNO-NITG, 2004. Geological Atlas of the Subsurface of the Netherlands - onshore. Netherlands Institute of Applied Geoscience TN0 (Utrecht), $104 \mathrm{pp}$.

Van Adrichem Boogaert, H.A. \& Kouwe, W.F.P., 1993. Stratigraphic nomenclature of the Netherlands, revision and update by RGD and NOGEPA, Section A, General. Mededelingen Rijks Geologische Dienst 50: 1-40.

Van Balen, R.T., Van Bergen, F., De Leeuw, C., Pagnier, H., Simmelink, H., Van Wees, J.D. \& Verweij, H., 2000. Modelling the hydrocarbon generation and migration in the West Netherlands Basin, the Netherlands. Netherlands Journal of Geosciences 79: 29-44.

Van Bergen, M.J. \& Sissingh, W., 2007. Magmatism in the Netherlands: expression of the north-west European rifting history. In: Wong, T.E., Batjes, D.A.J. \& De Jager, J. (eds): Geology of the Netherlands. Royal Netherlands Academy of Arts and Sciences (KNAW) (Amsterdam): 197-222.

Van Wees, J.D., Stephenson, R.A., Ziegler, P.A., Bayer, U., McCann, T., Dadlez, R., Gaupp, R., Narkiewicz, M., Bitzer, F. \& Scheck, M., 2000. On the origin of the Southern Permian Basin, Central Europe. Marine and Petroleum Geology 17: 43-59.

Van Wees, J.D., Van Bergen, F., David, P., Nepveu, M., Beekman, F., Cloetingh, S.A.P.L. \& Bonté, D., 2009. Probabilistic tectonic heat flow modeling for basin maturation: Assessment method and applications. Marine and Petroleum Geology 26: 536-551.

Verweij, H., 2006, Nitrogen in natural gas accumulations in onshore and offshore Netherlands. Report TN0 Built Environment and Geosciences (Utrecht), 25 pp.

Verweij, J.M., 2008. Isotopic signature of nitrogen: an indicator for timing $\mathrm{N}_{2}$ generation and $\mathrm{N}_{2}$ charging of Dutch natural gas accumulations. $70^{\text {th }}$ EAGE Conference \& Exhibition (Rome).

Verweij, J.M., Souto Carneiro Echternach, M. \& Witmans, N., 2009. Terschelling Basin and southern Dutch Central Graben. Burial history, temperature, source rock maturity and hydrocarbon generation - Area 2A. TN0 (Utrecht), Report number 034-UT-2009-02065.
Verweij, J.M., Souto Carneiro Echternach, M. \& Witmans, N., 2010. Central Offshore Platform - Area NCP2E. Burial history, temperature, source rock maturity and hydrocarbon generation. TNO Built Environment and Geosciences - National Geological Survey (Utrecht, the Netherlands). Report number TNO034-UT-2010-01298/A.

Verweij, J.M., Souto Carneiro Echternach, M., Witmans, N. \& Abdul Fattah, R., 2012. Reconstruction of basal heat flow, surface temperature, source rock maturity and hydrocarbon generation in salt-dominated Dutch Basins. In: Peters, K., Curry, D. \& Kacewicz, M. (eds): Basin Modeling: New horizons in research and applications. AAPG Hedberg Series: 1-22.

Wong, T.E., Batjes, D.A.J. \& De Jager, J. (eds), 2007. Geology of the Netherlands. Royal Netherlands Academy of Arts and Sciences (KNAW) (Amsterdam), $354 \mathrm{pp}$.

Ziegler, P.A., 1990. Geological Atlas of Western and Central Europe ( $2^{\text {nd }}$ edition). Shell Internationale Petroleum Maatschappij B.V., Geological Society Publishing House (Bath), 239 pp. 